Supporting Information for

\title{
Remote Electronic Effects by Ether Protecting Groups Fine-Tune Glycosyl Donor Reactivity
}

\author{
Mads Heuckendorff, Lulu Teressa Poulsen and Henrik H. Jensen* \\ Contribution from the Department of Chemistry, Aarhus University, Langelandsgade 140 \\ DK-8000 Aarhus C, Denmark \\ E-mail: hhj@chem.au.dk
}




\section{${ }^{1} \mathrm{H}$ and ${ }^{13} \mathrm{C}$ NMR Spectra for Compounds.}

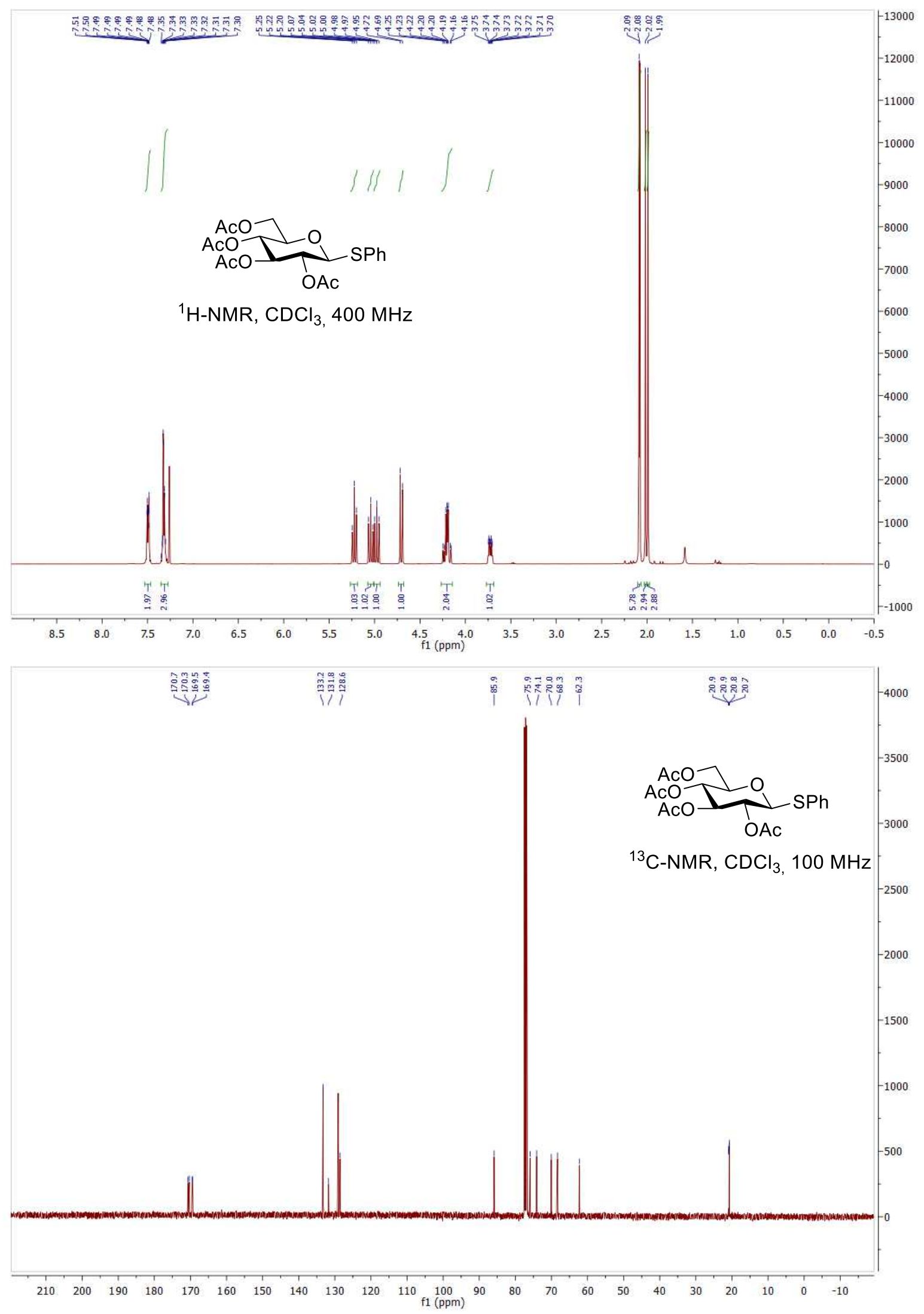



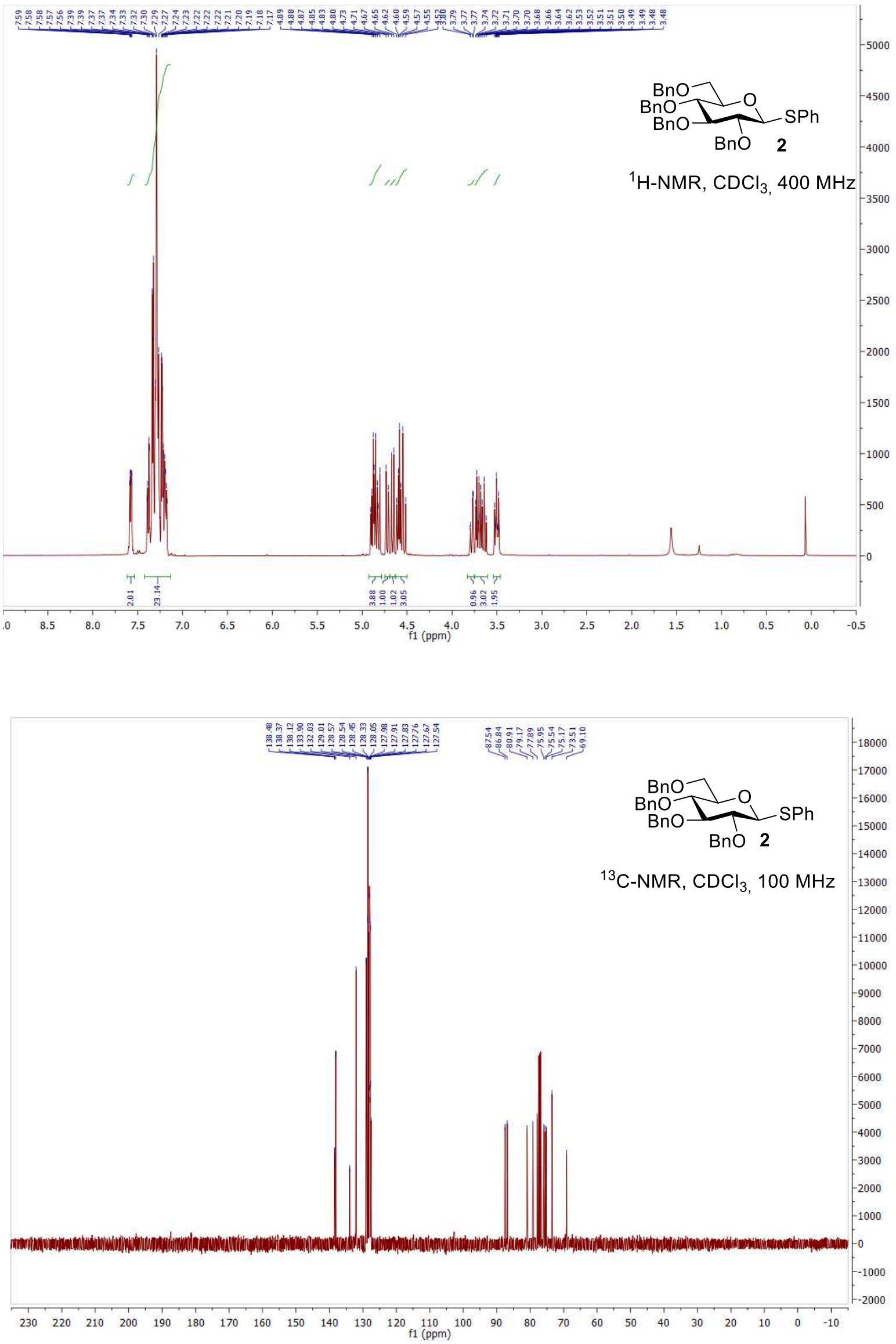

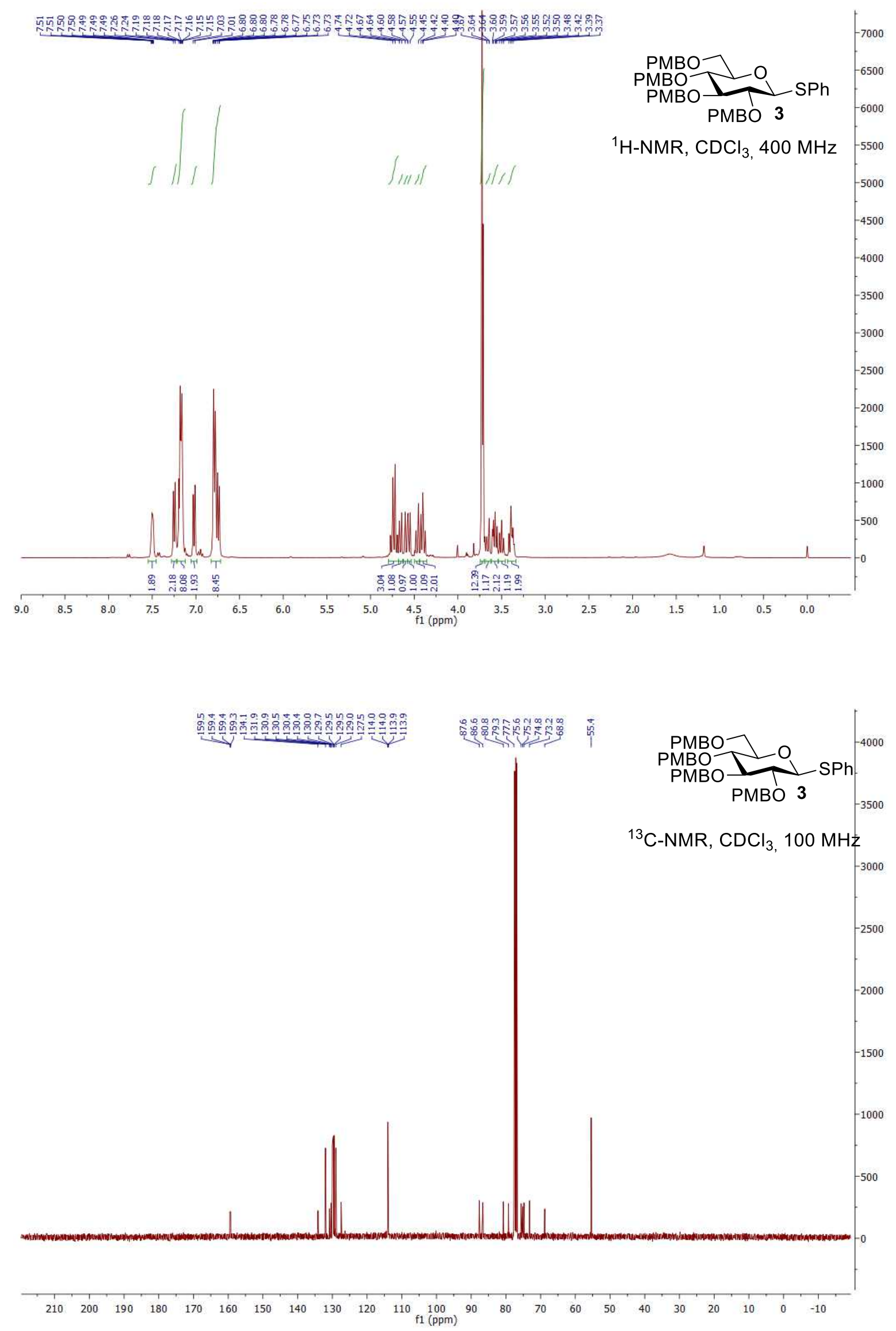


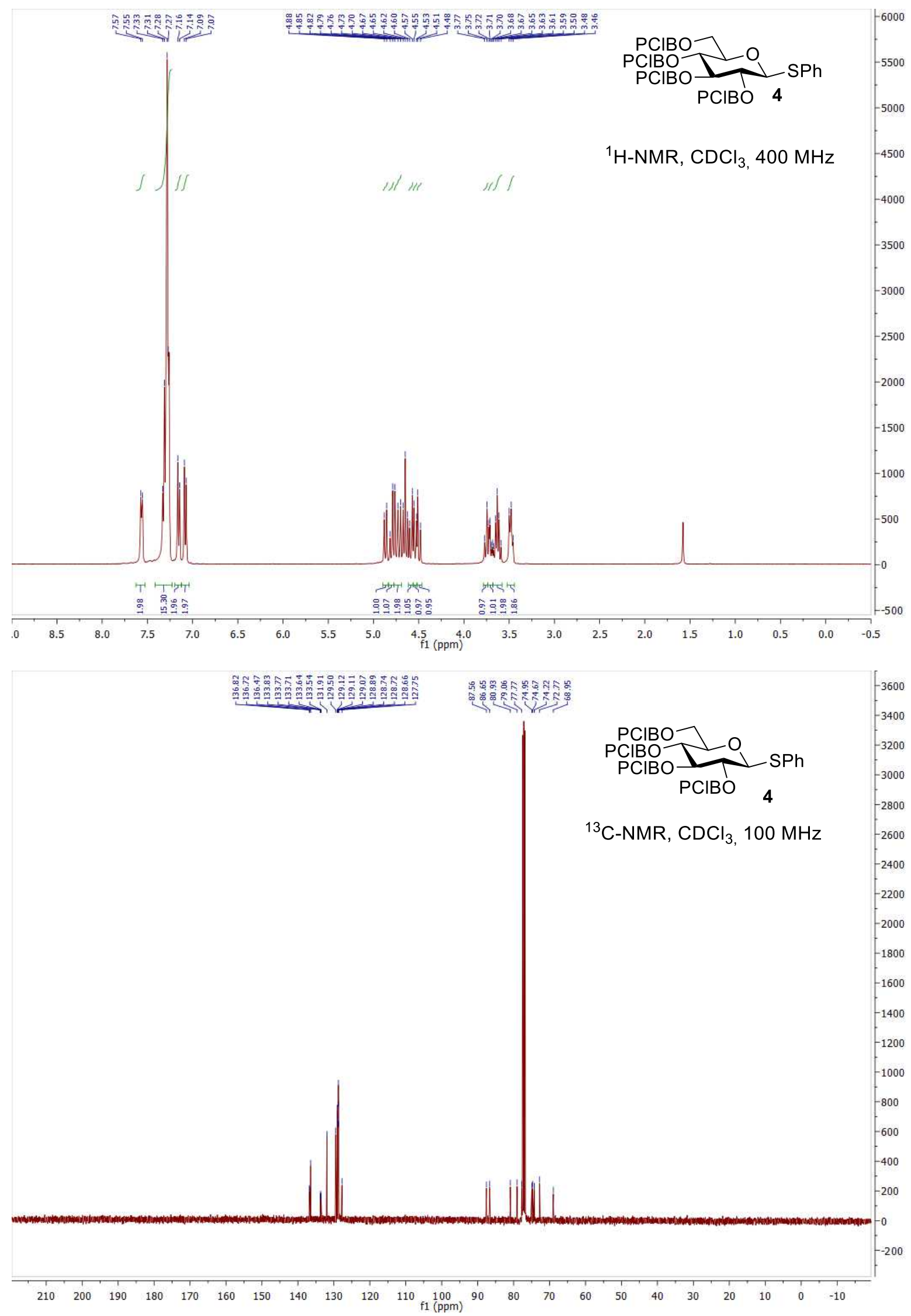




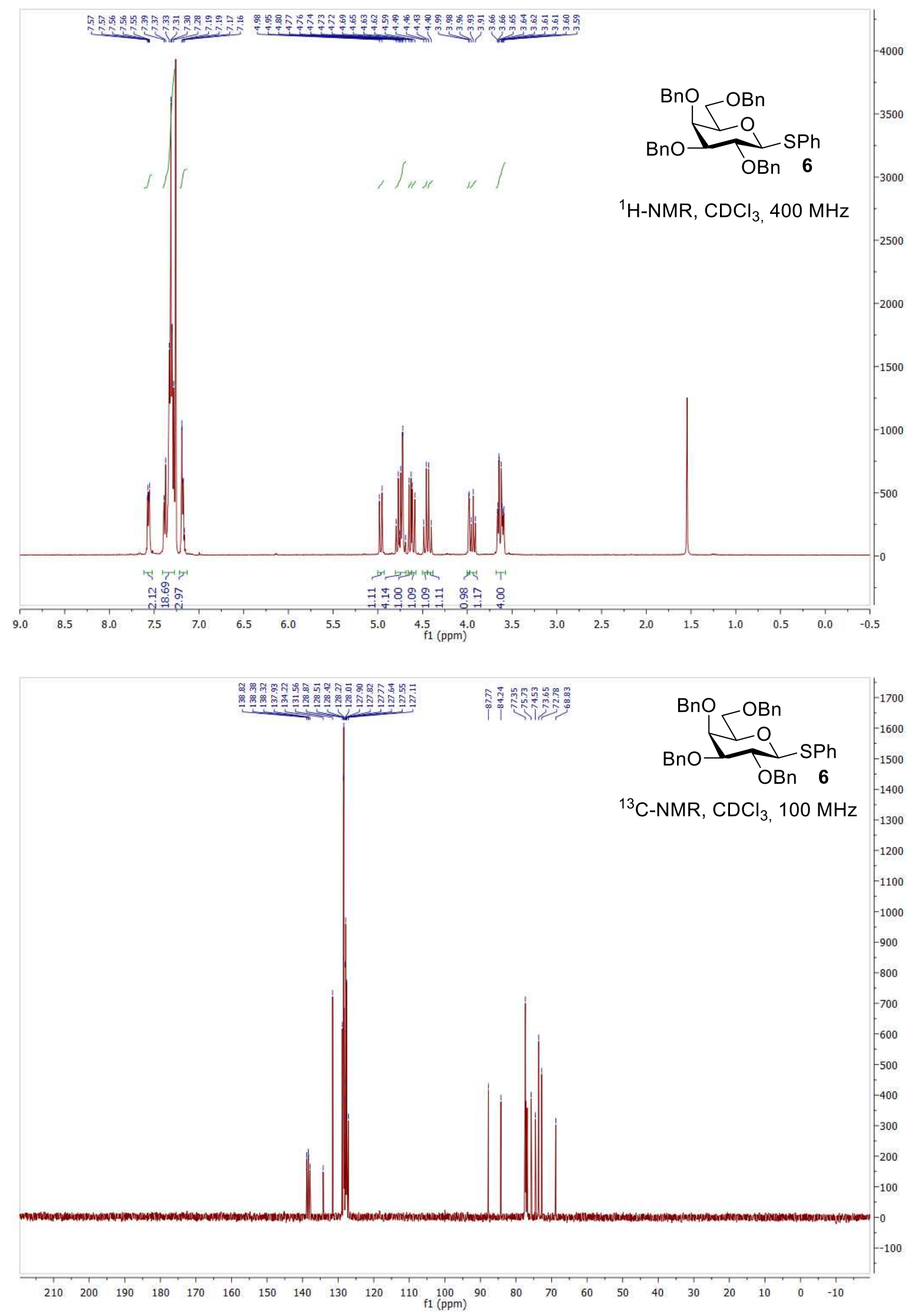



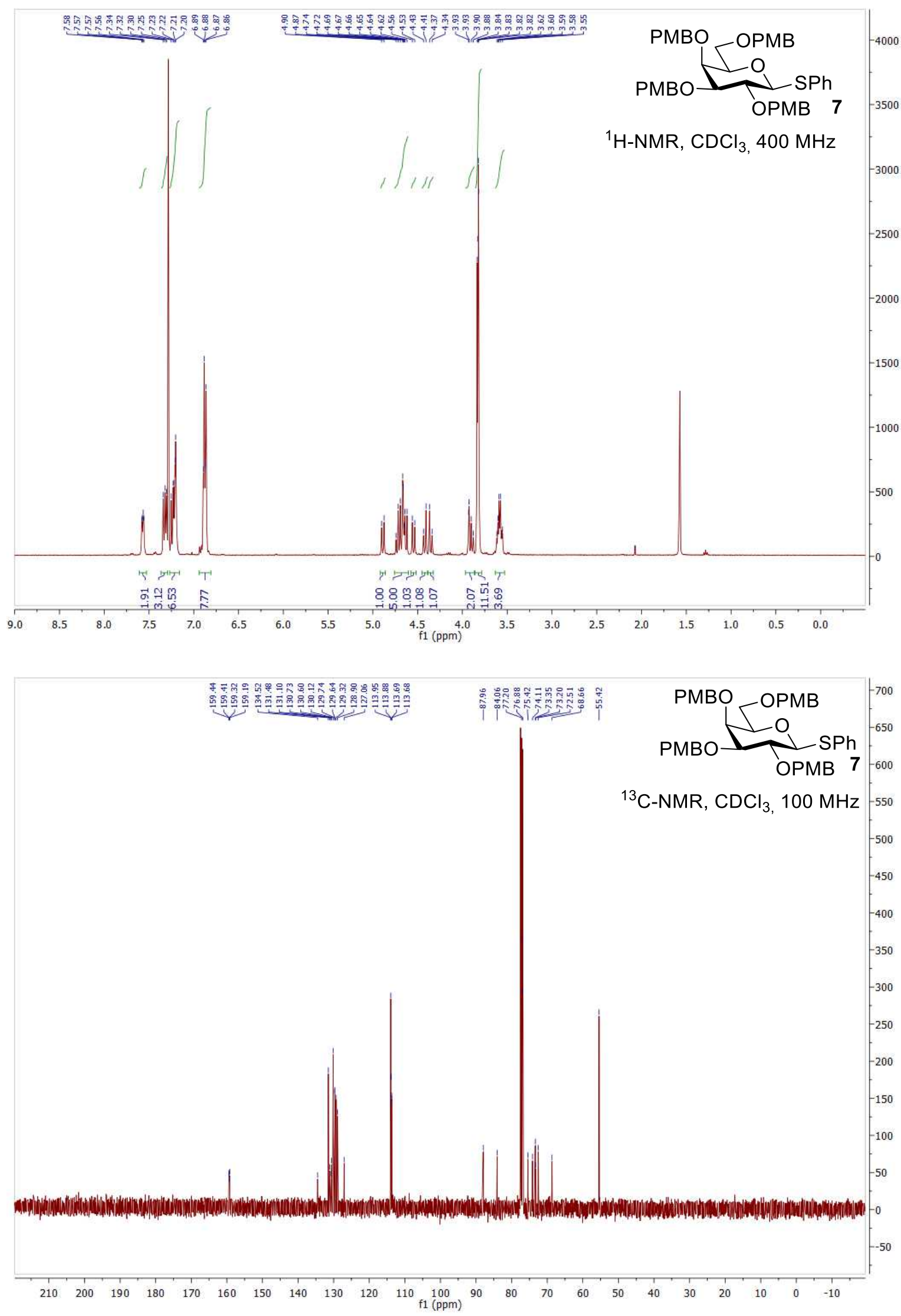

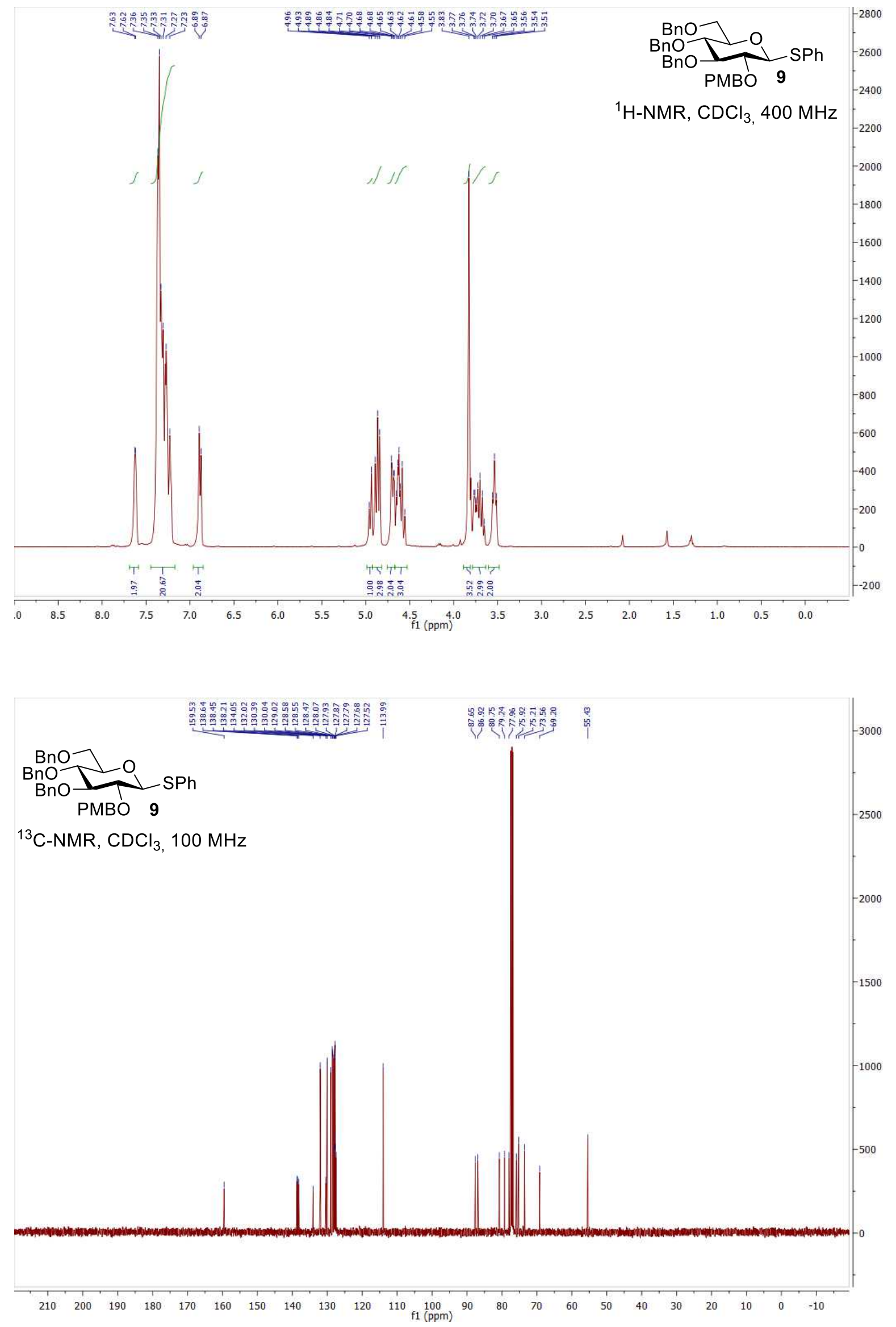

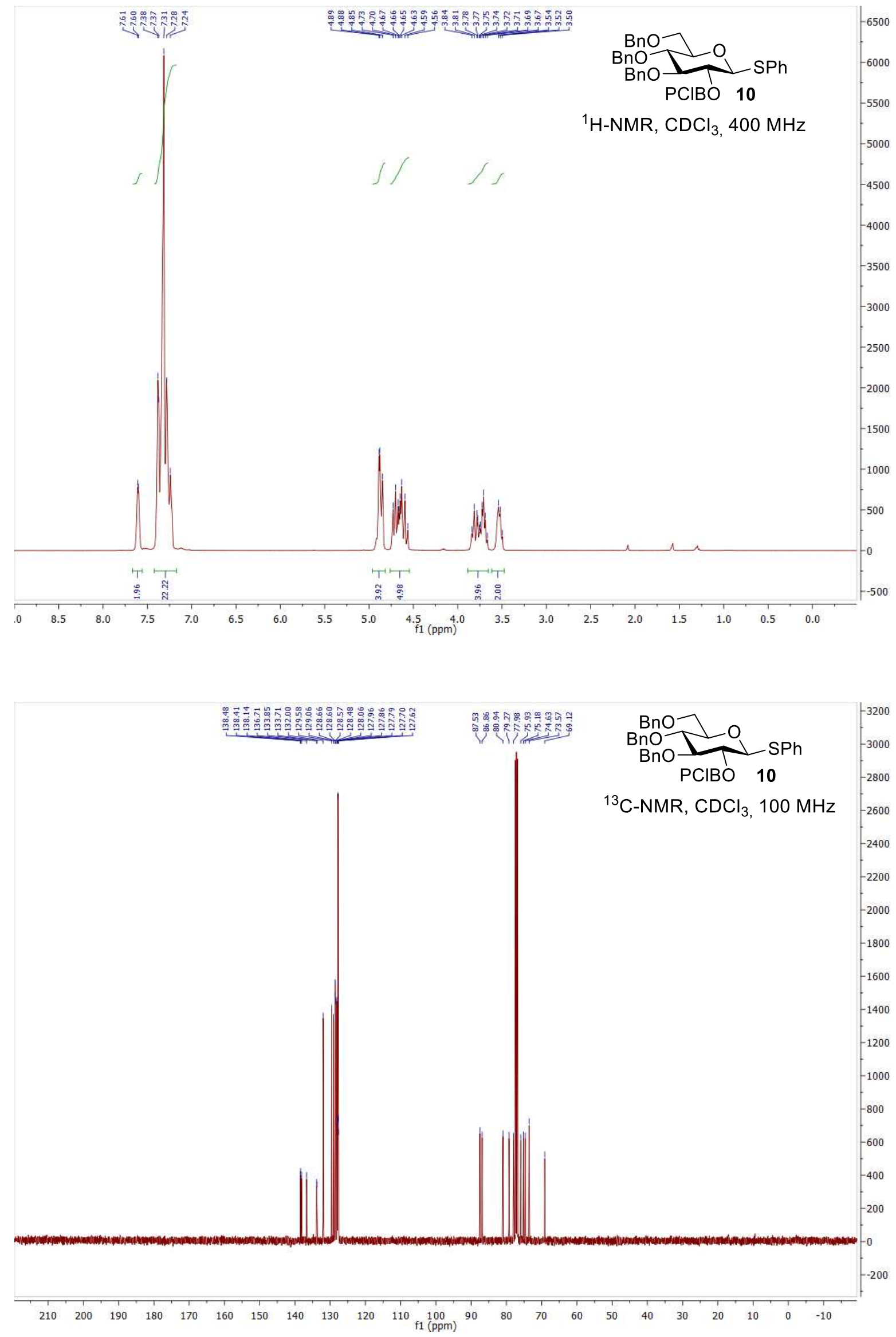

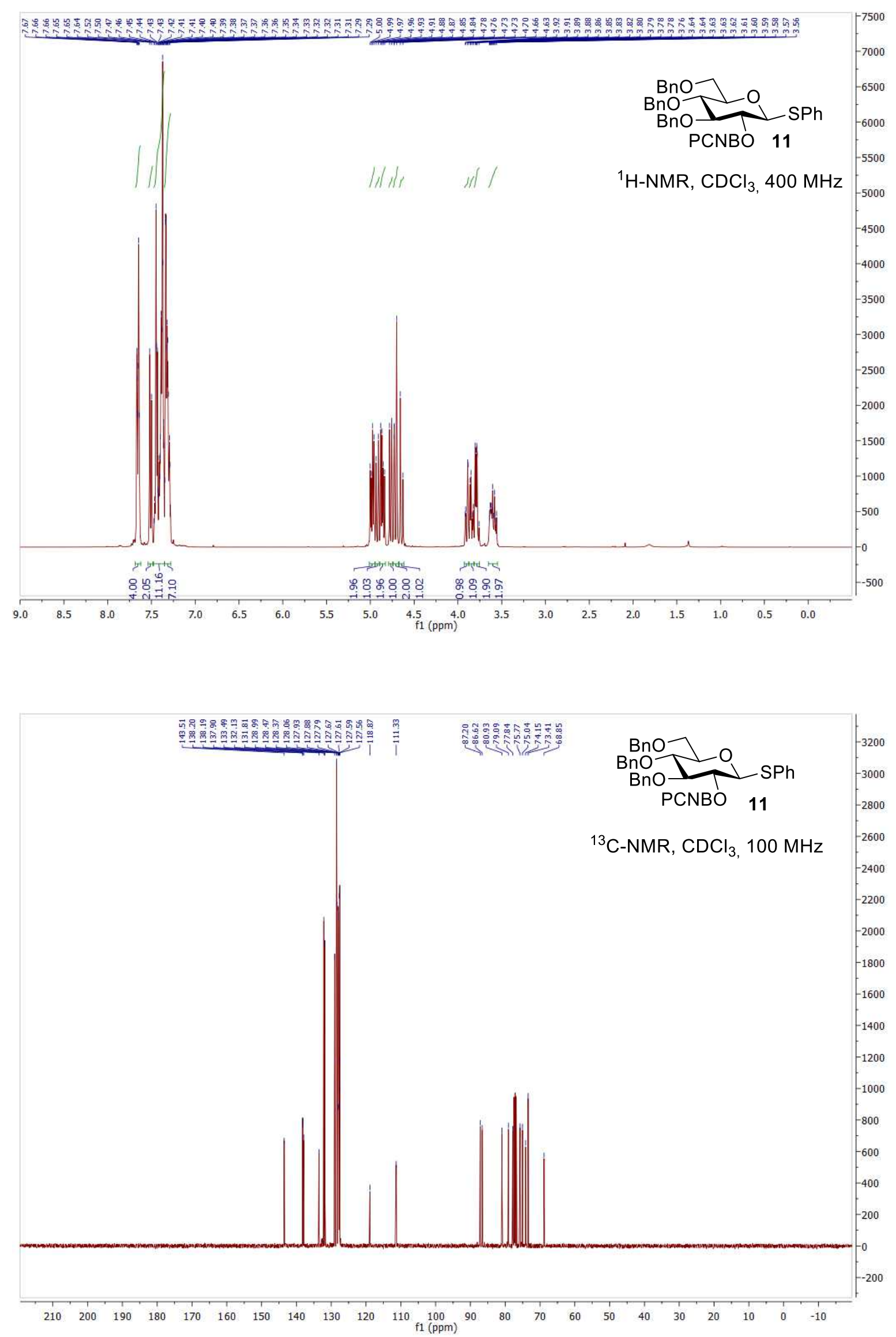

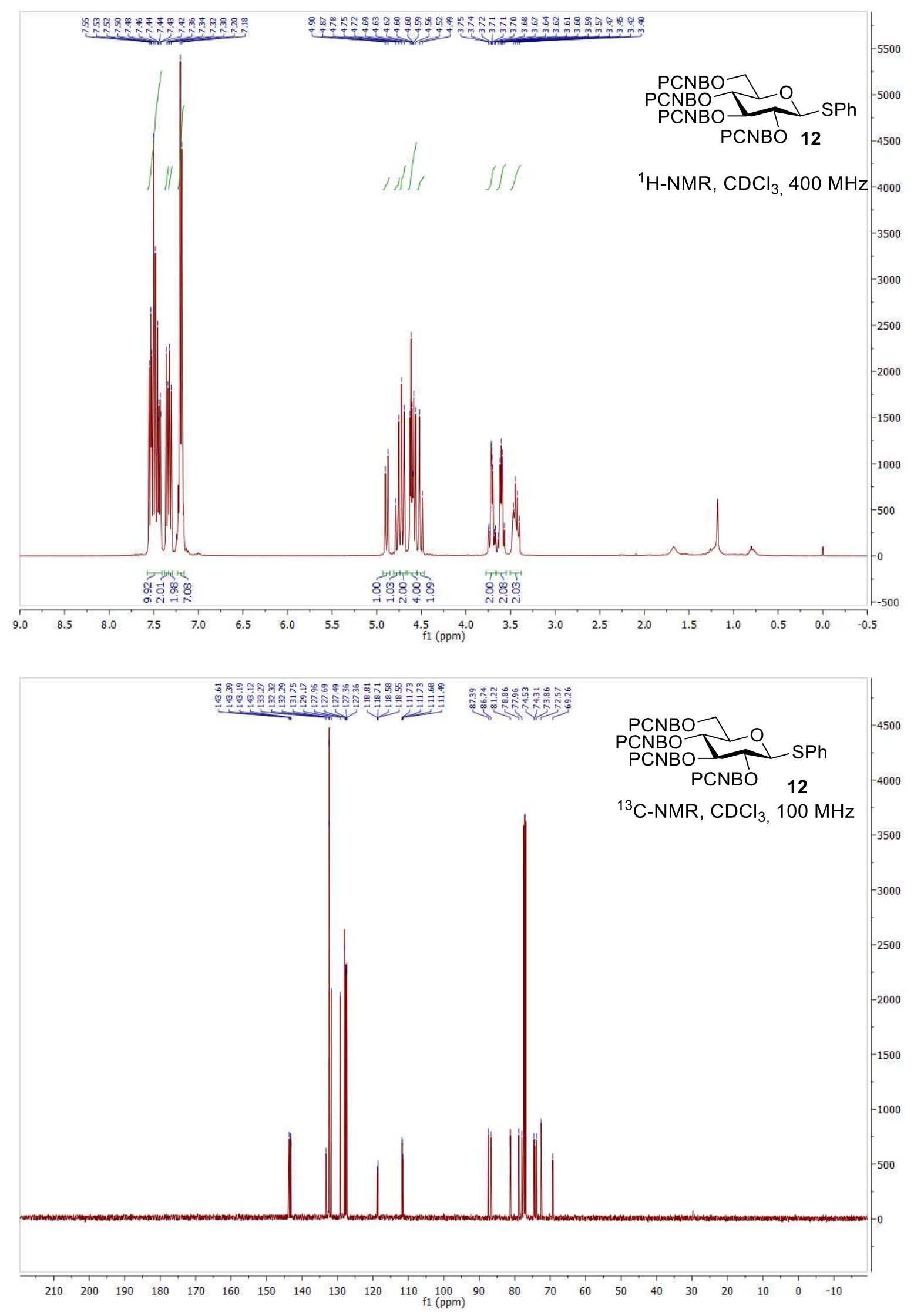

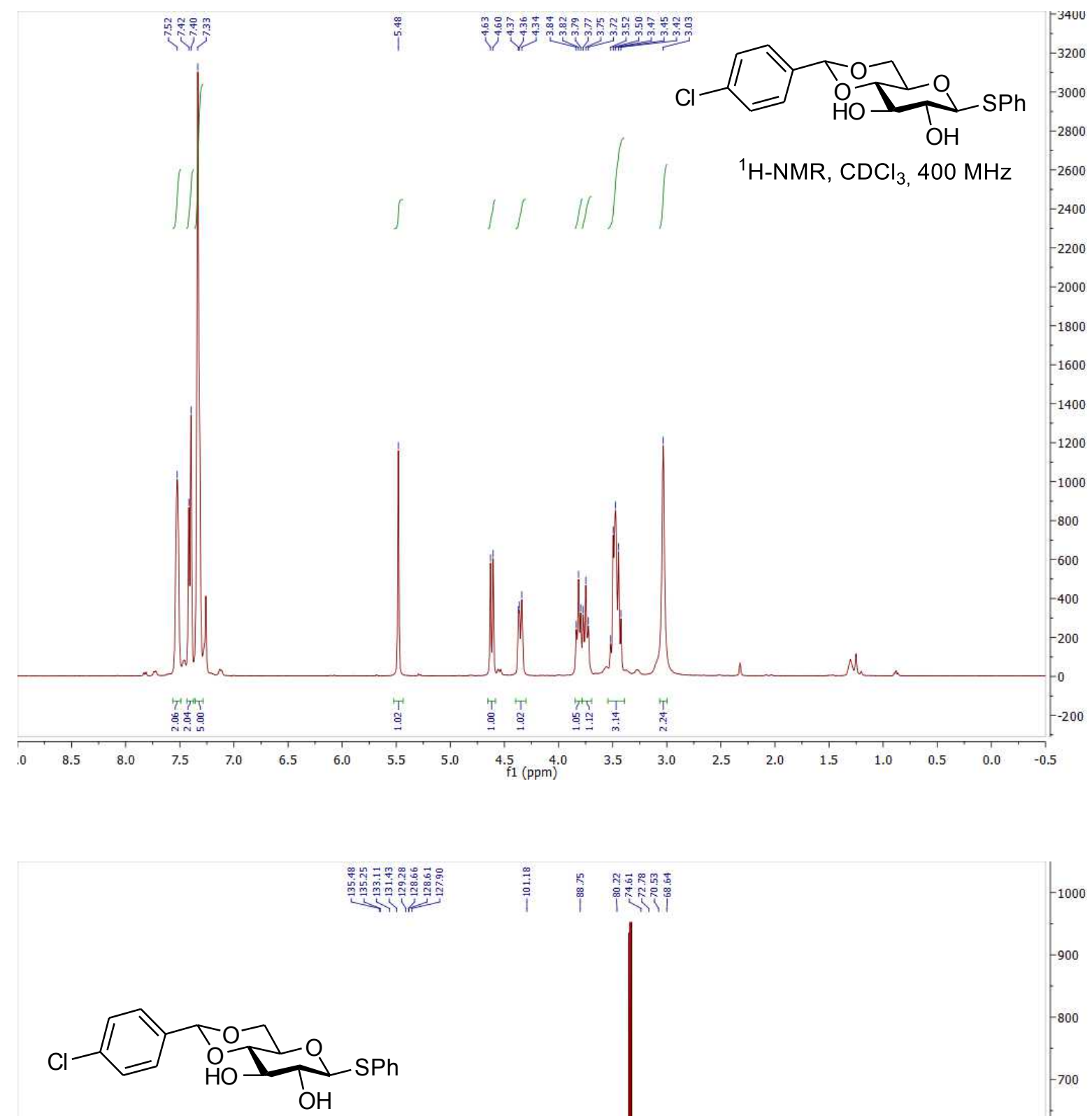

${ }^{13} \mathrm{C}-\mathrm{NMR}, \mathrm{CDCl}_{3}, 100 \mathrm{MHz}$
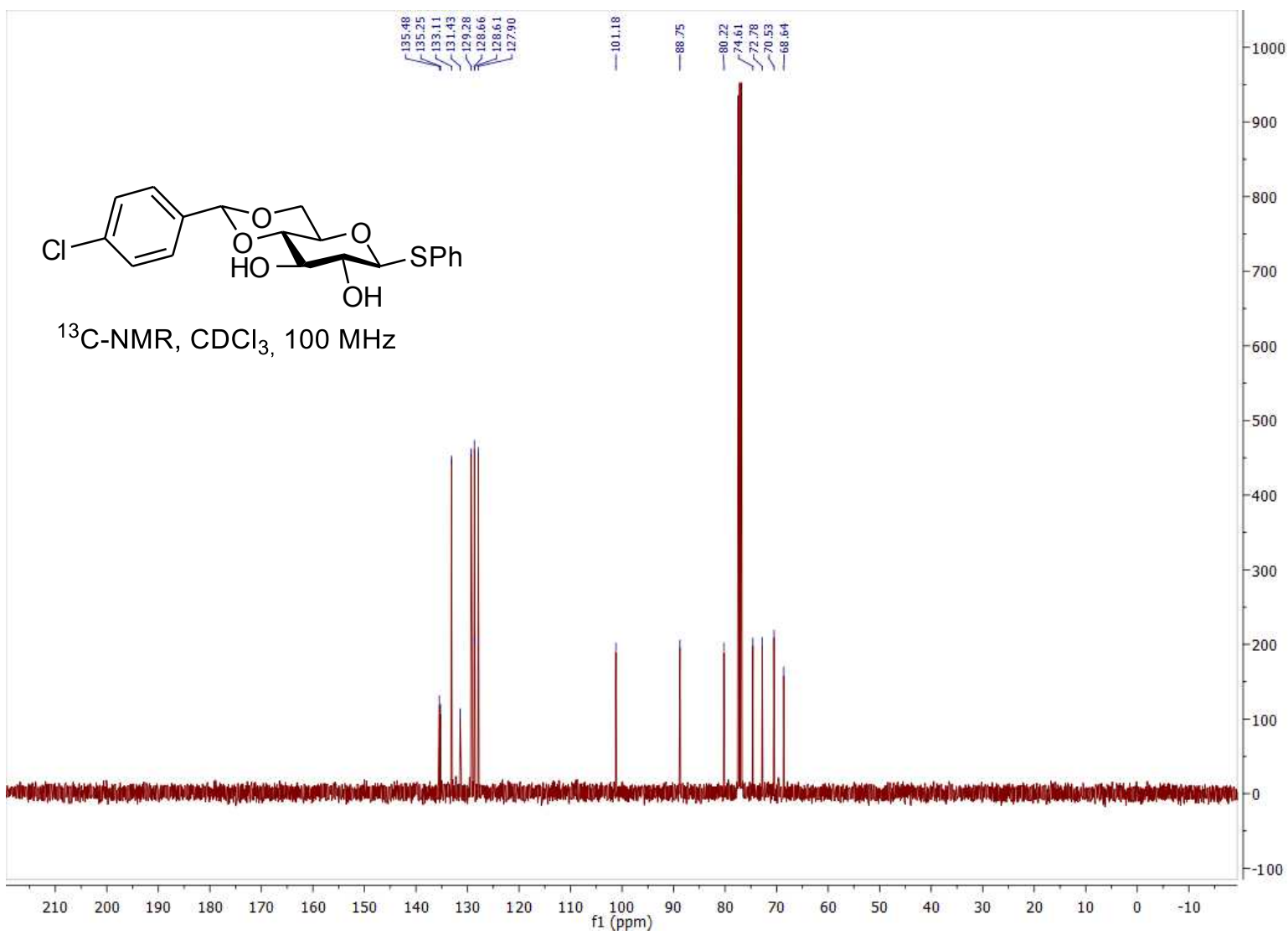

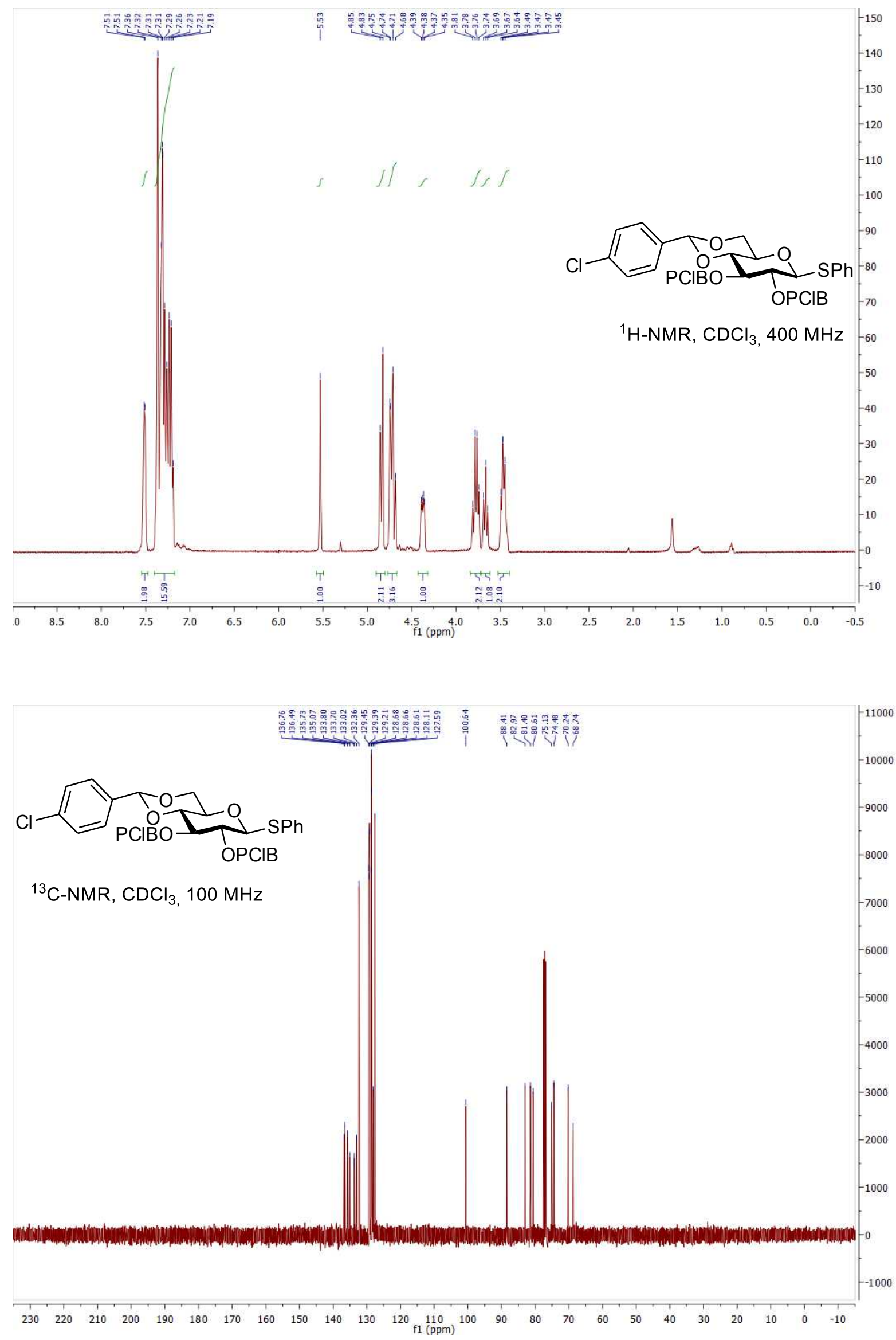

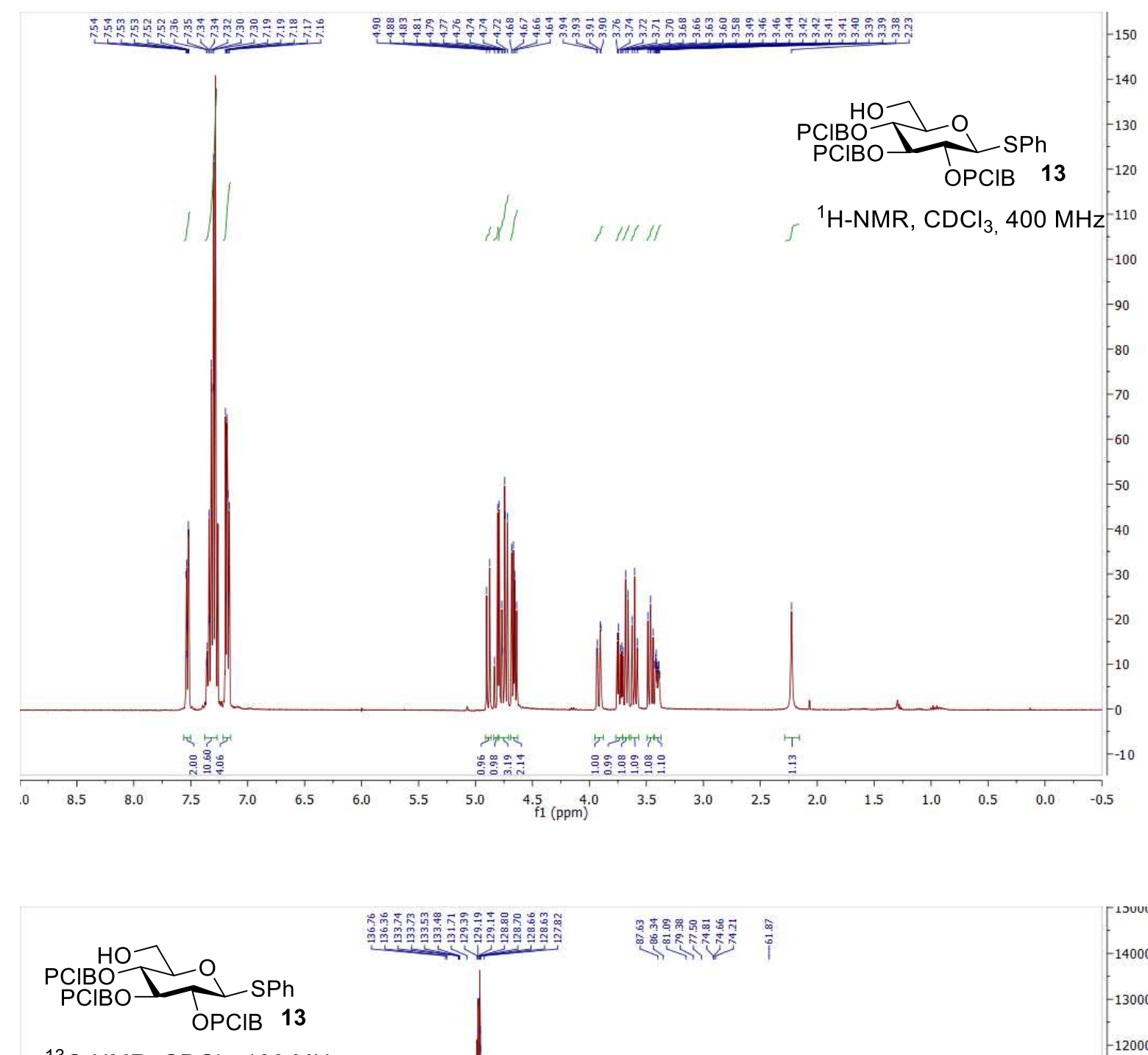

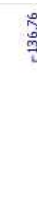

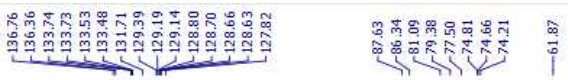

${ }^{13} \mathrm{C}-\mathrm{NMR}, \mathrm{CDCl}_{3}, 100 \mathrm{MHz}$ 

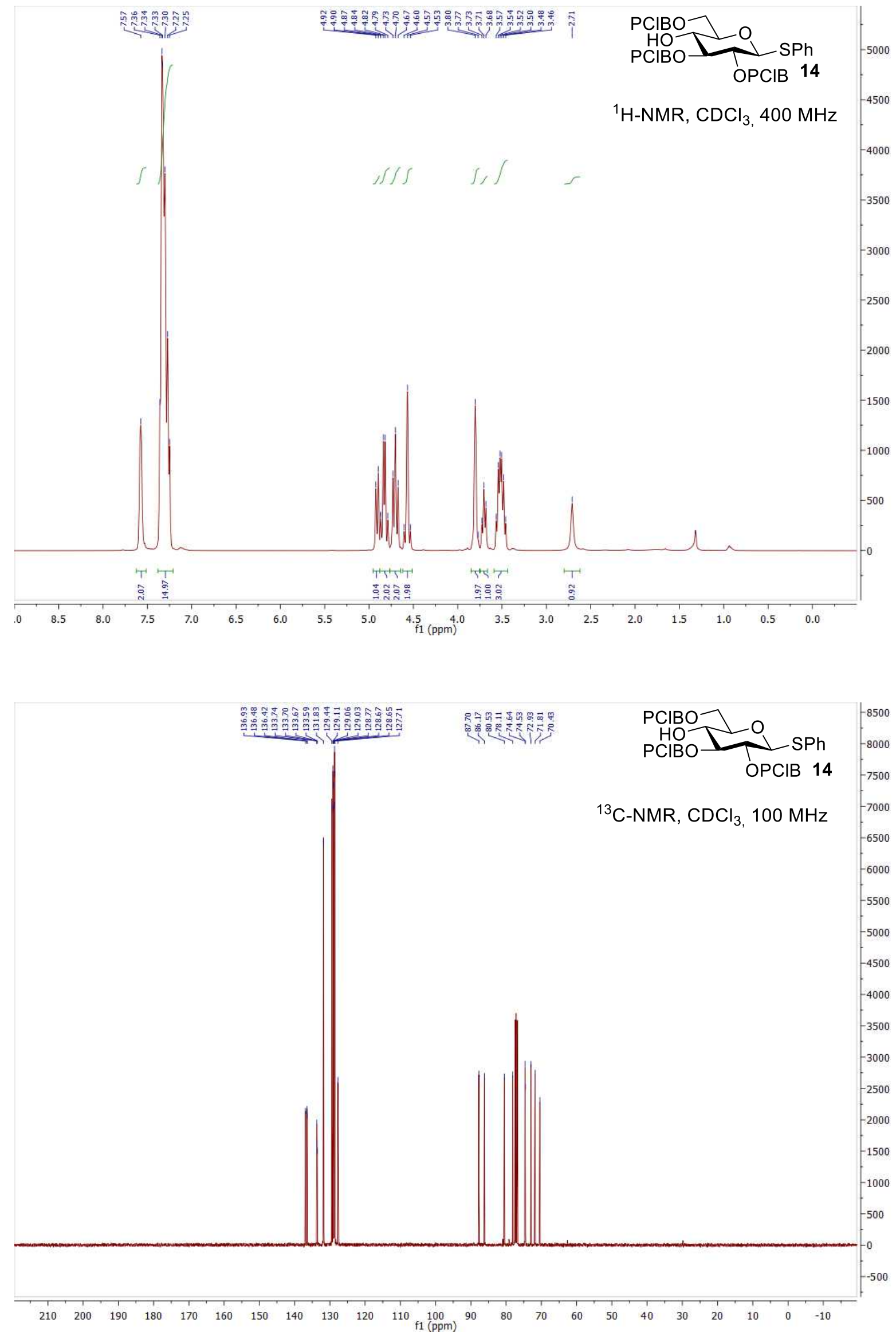

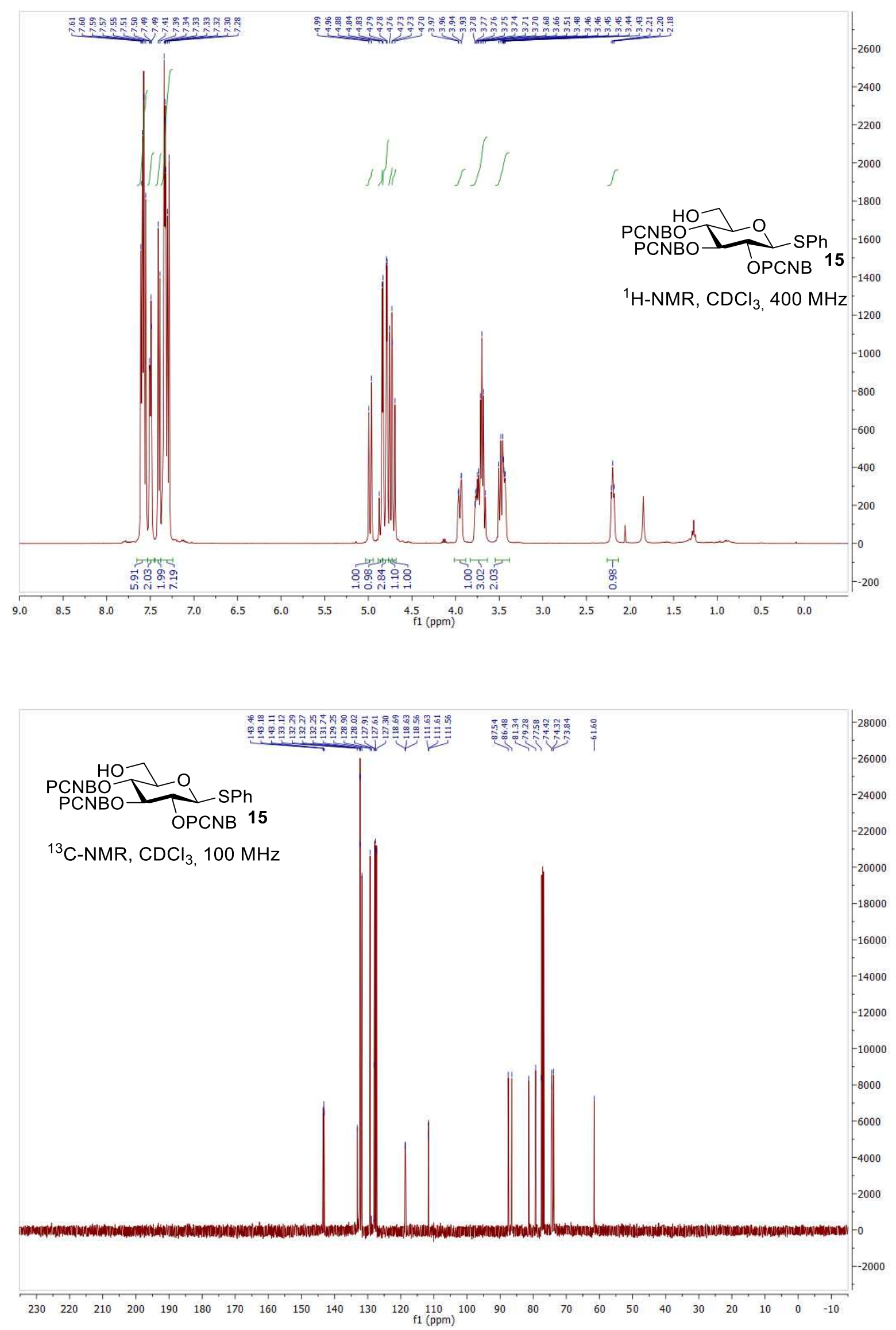

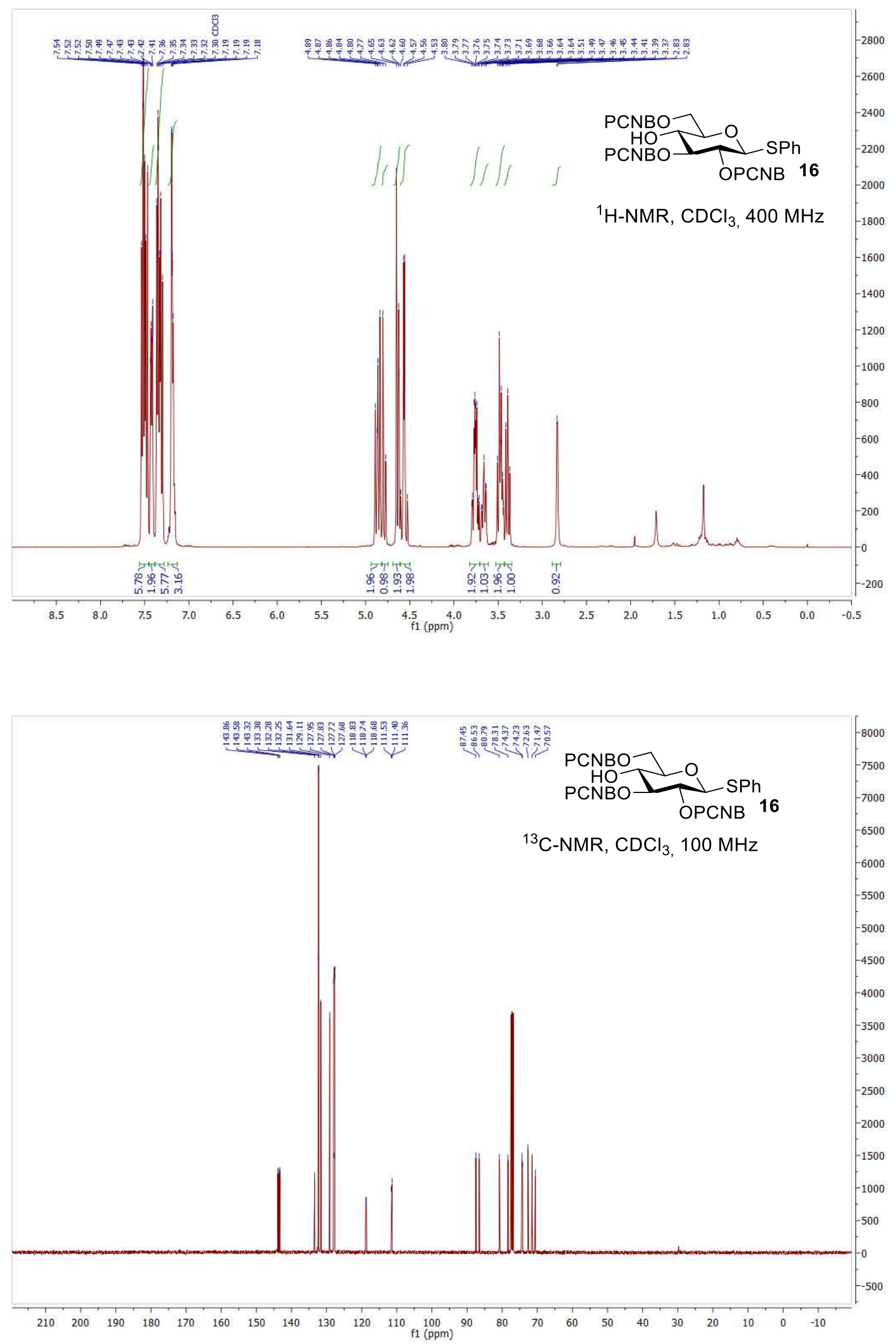

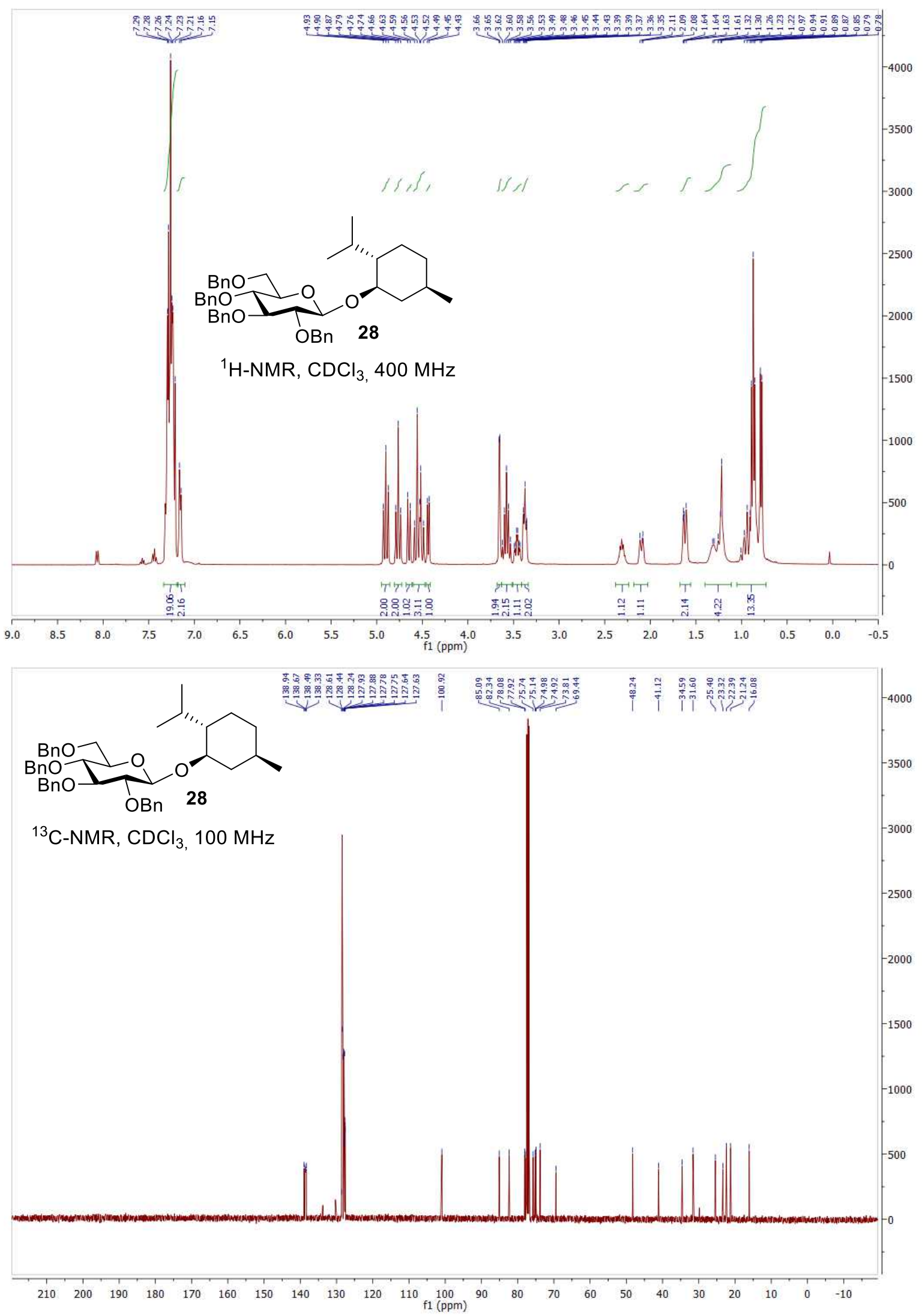


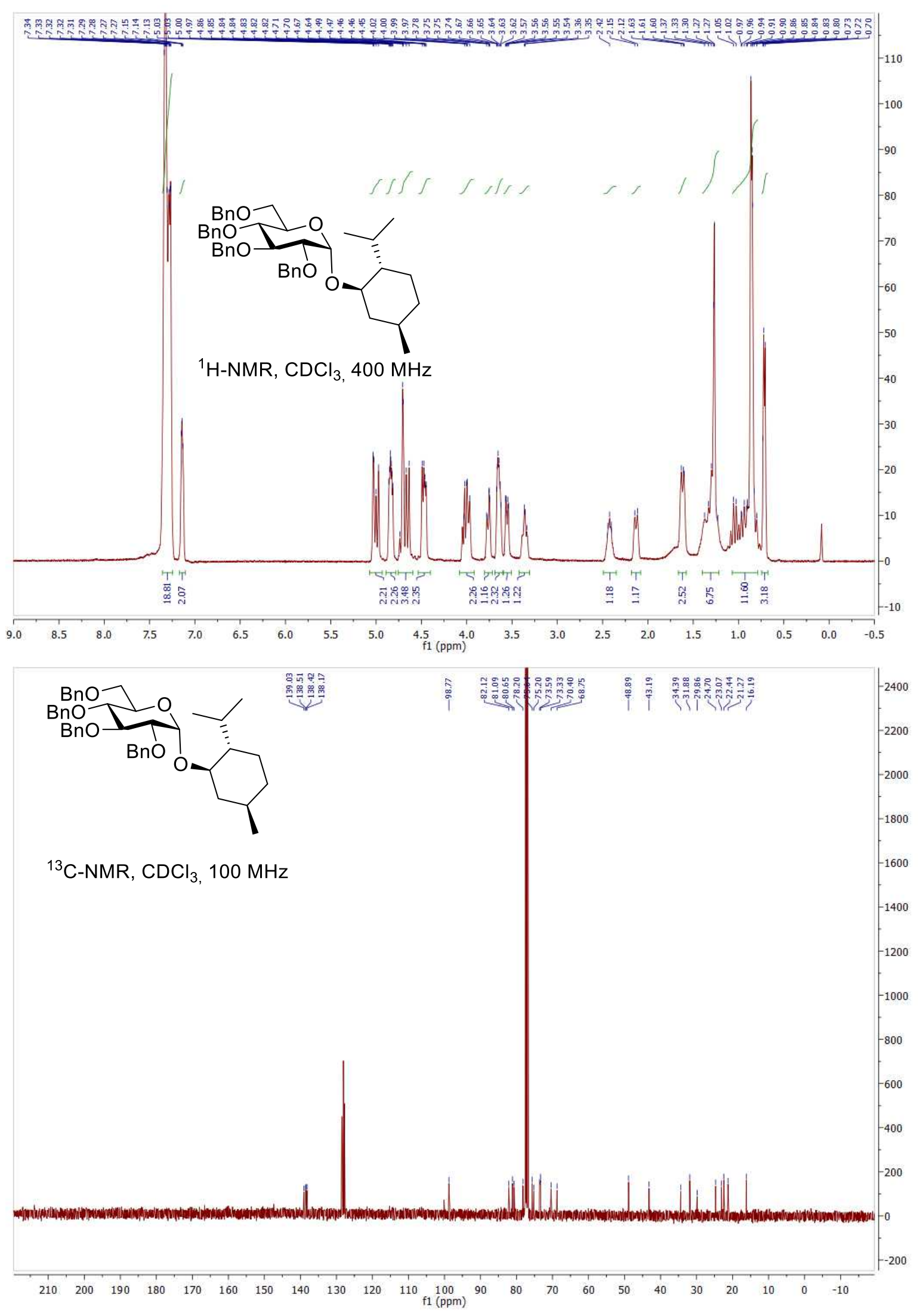



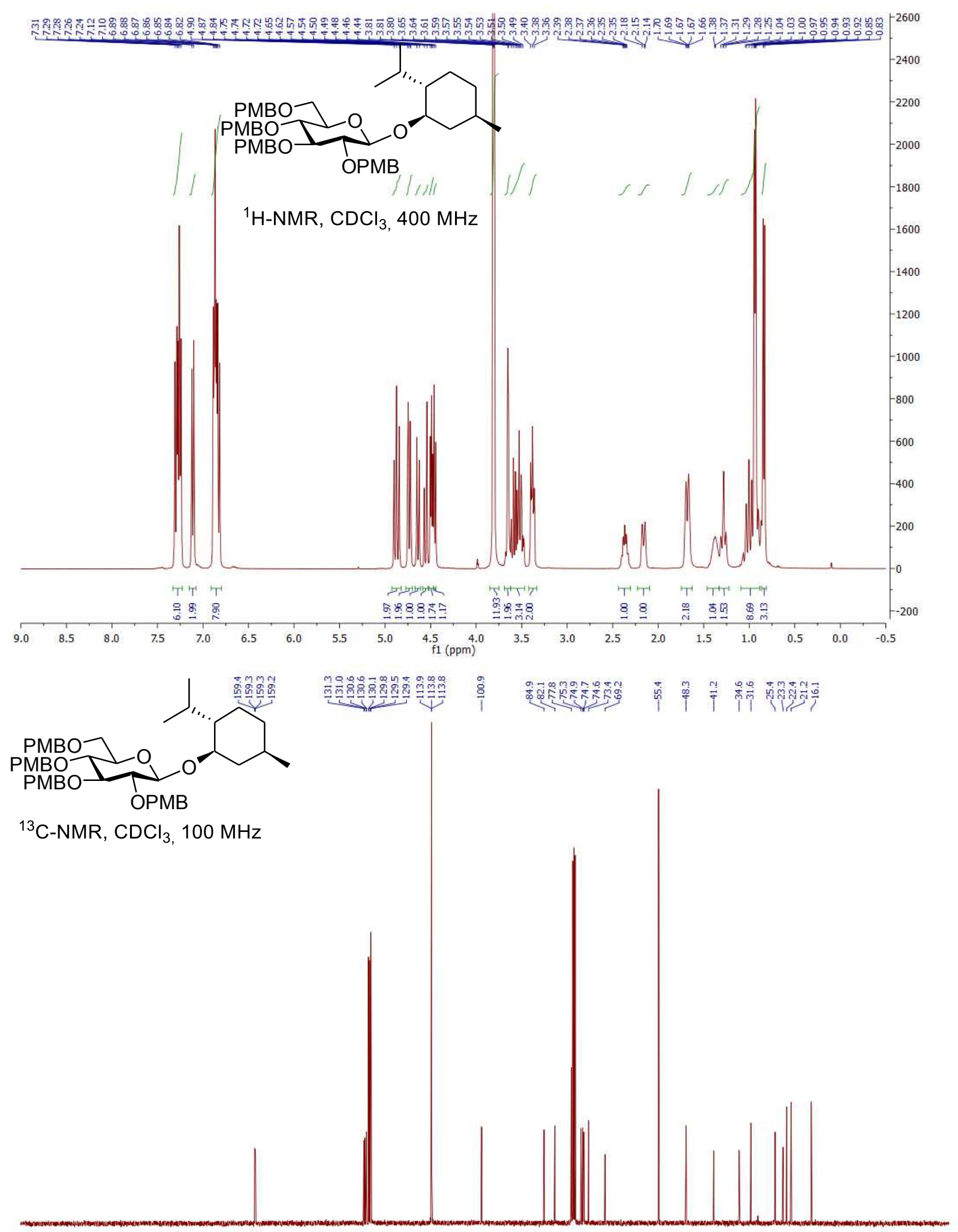

$\begin{array}{llllllllllllllllllllllllllll}210 & 200 & 190 & 180 & 170 & 160 & 150 & 140 & 130 & 120 & 110 & 100 & 90 & 80 & 70 & 60 & 50 & 40 & 30 & 20 & 10 & 0 & -10\end{array}$ 


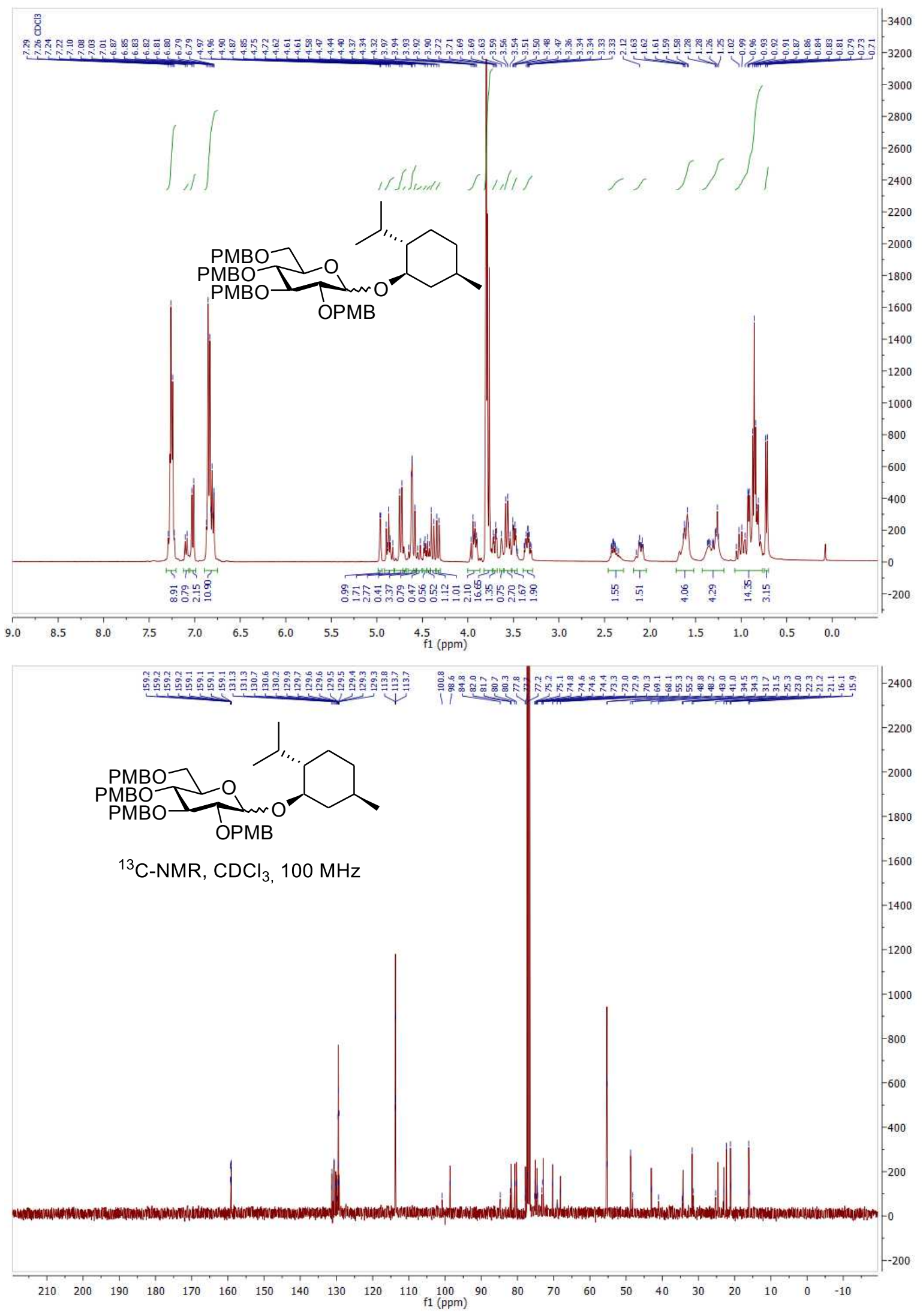



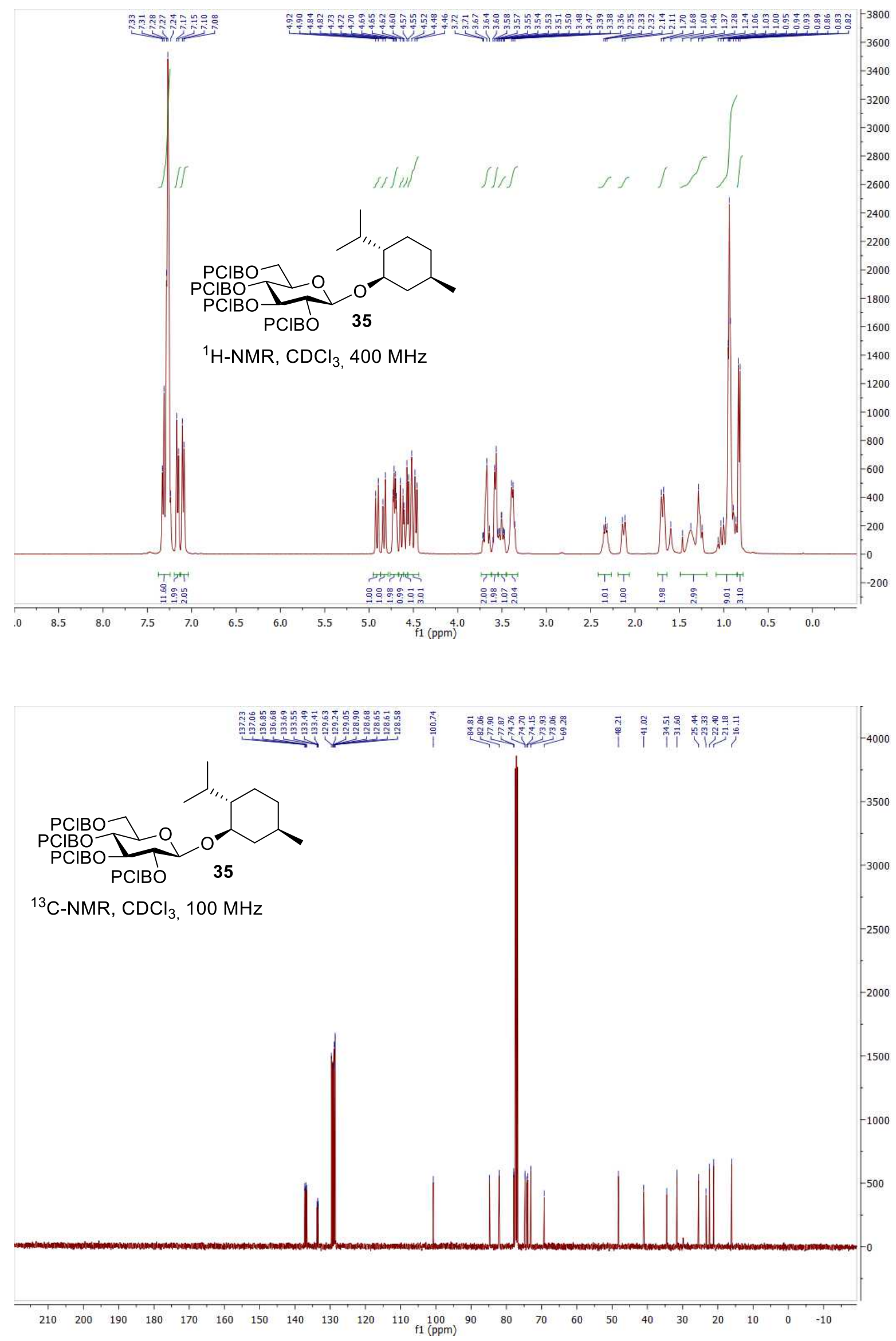

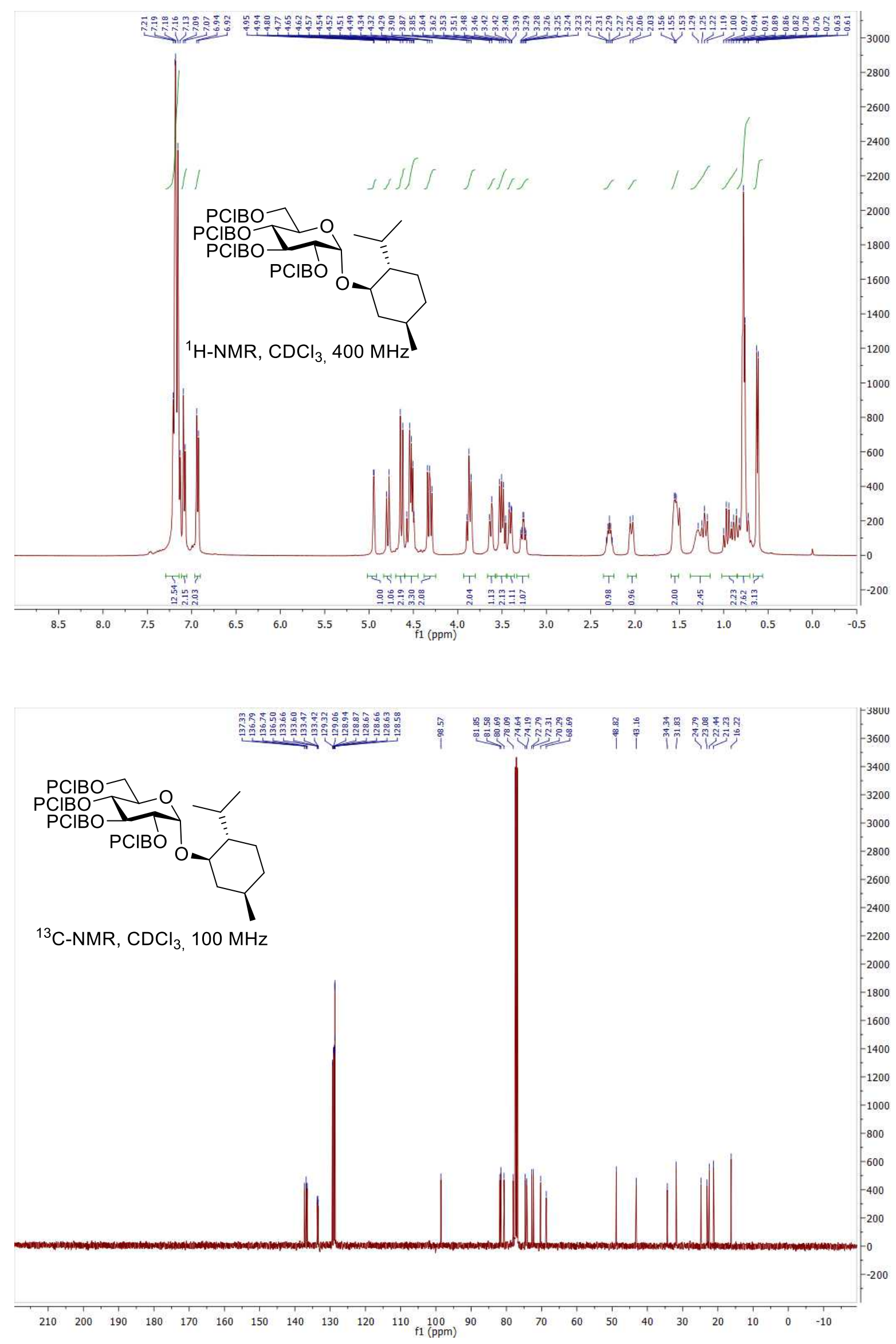

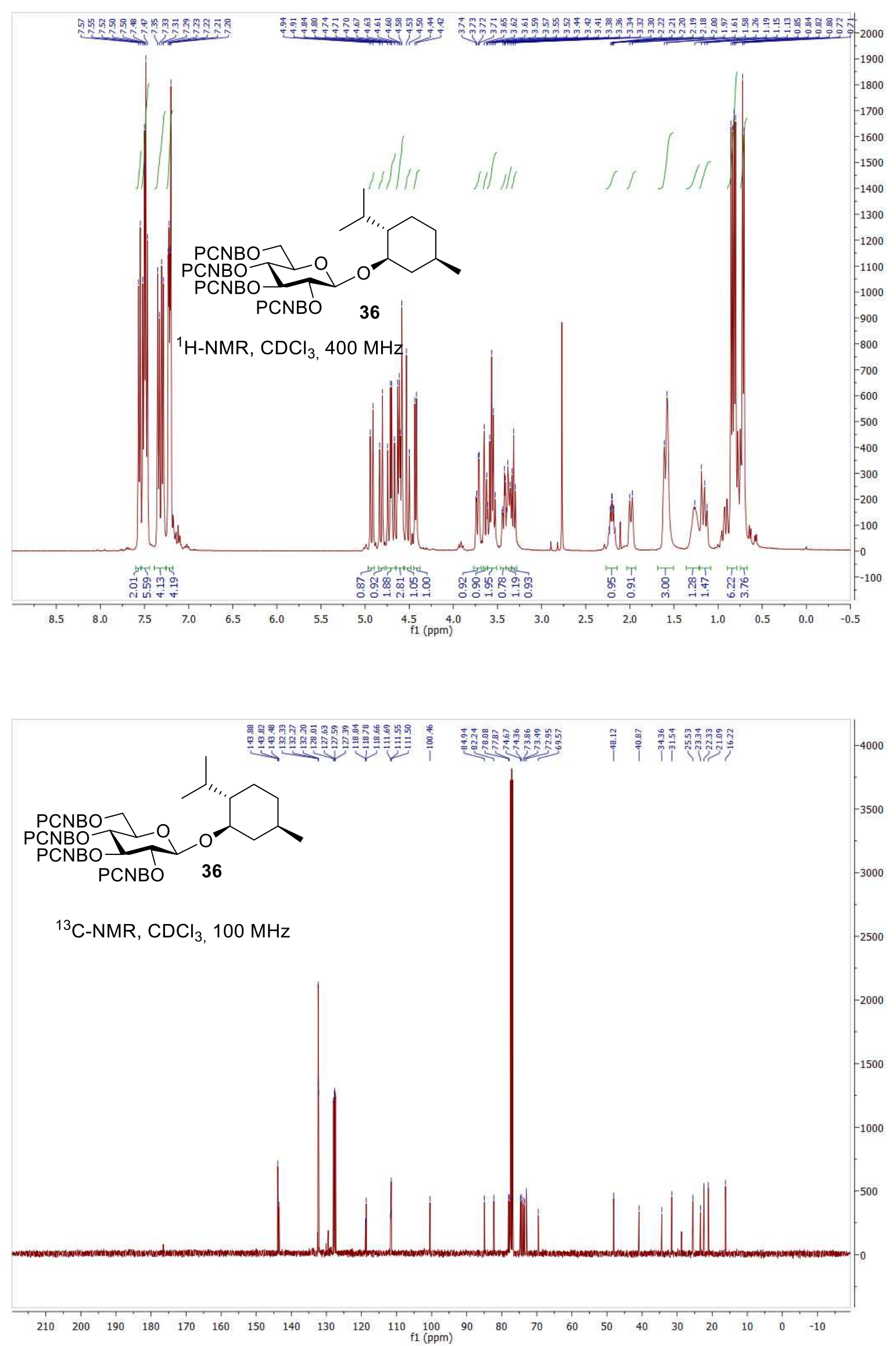

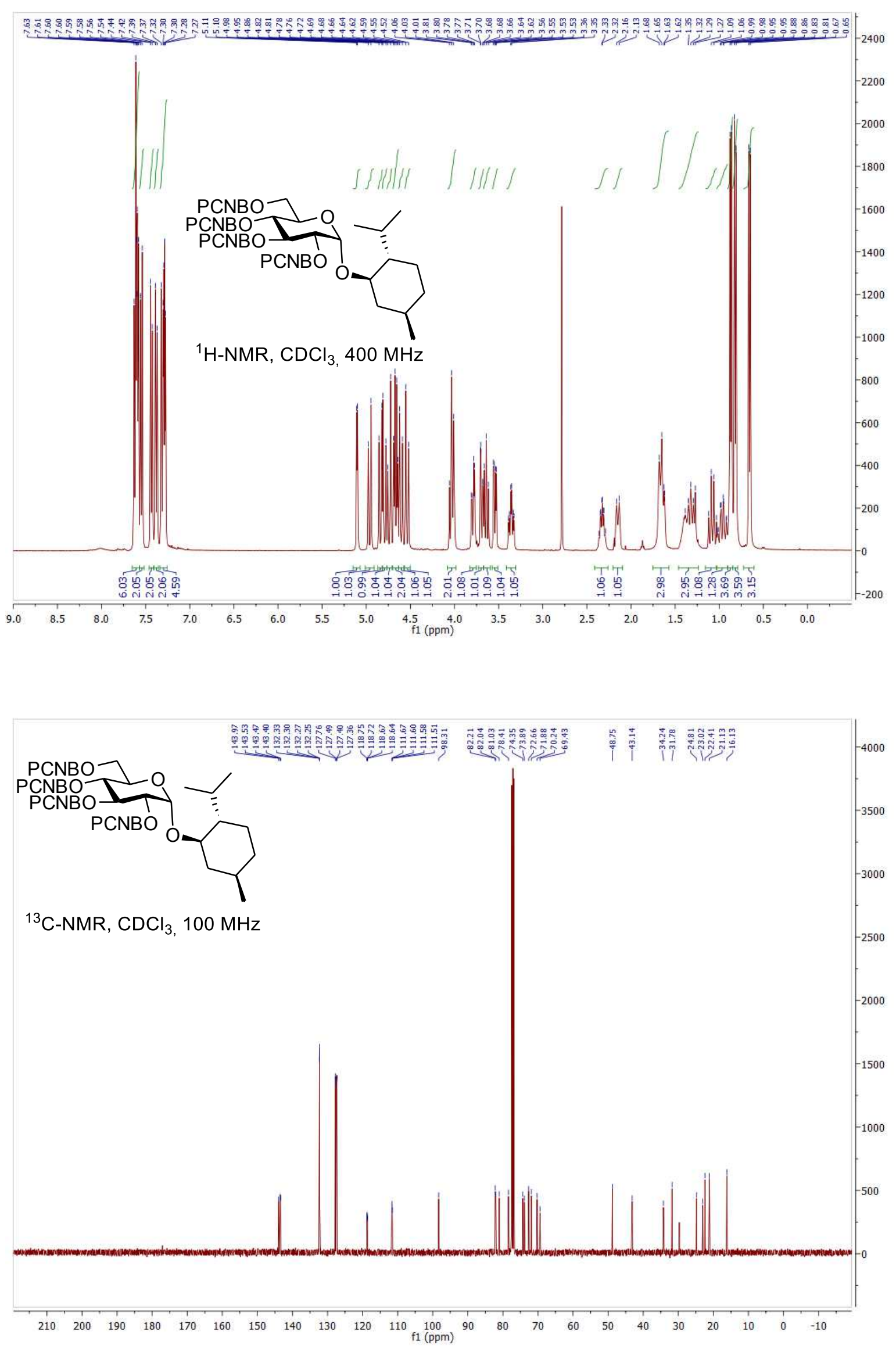

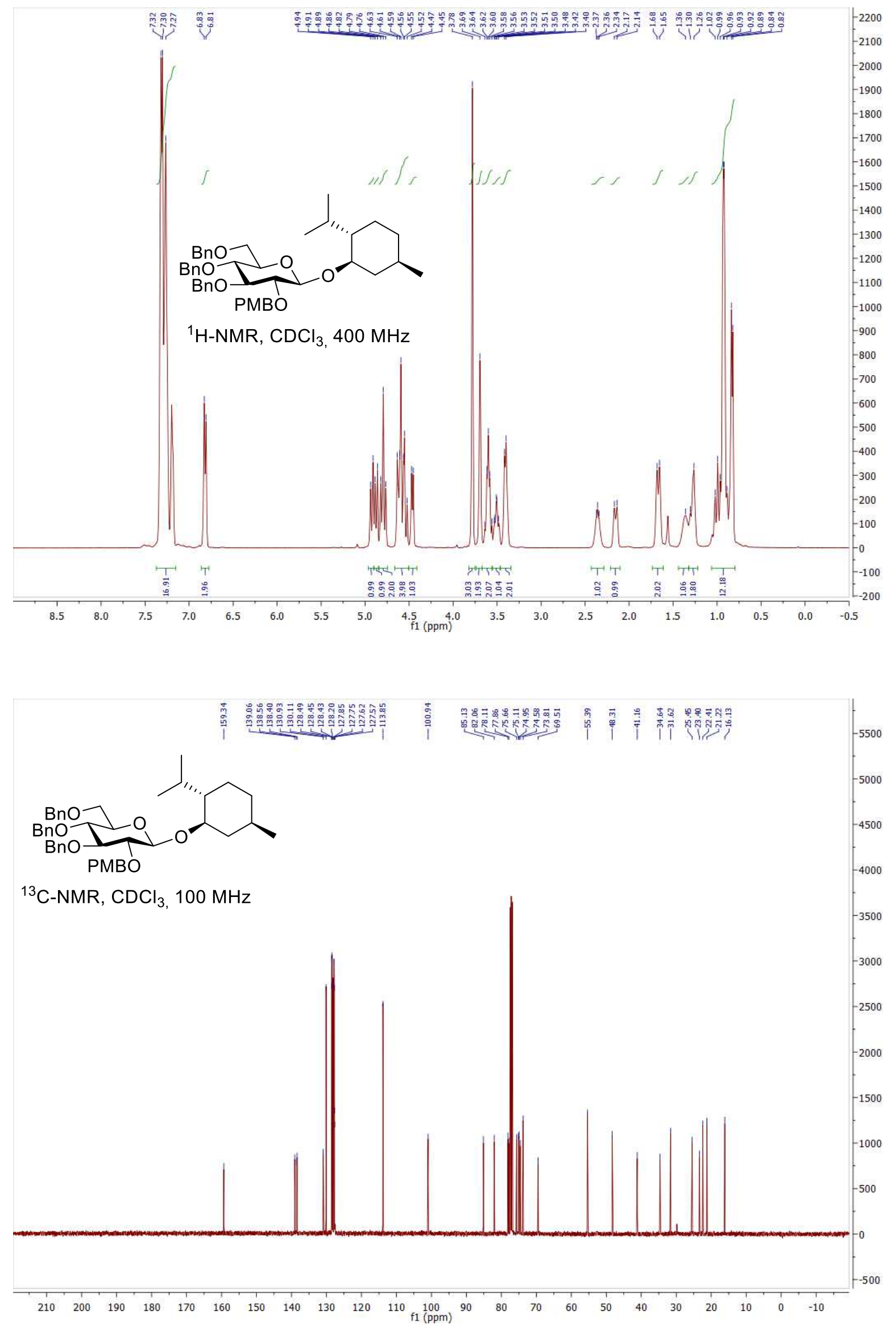

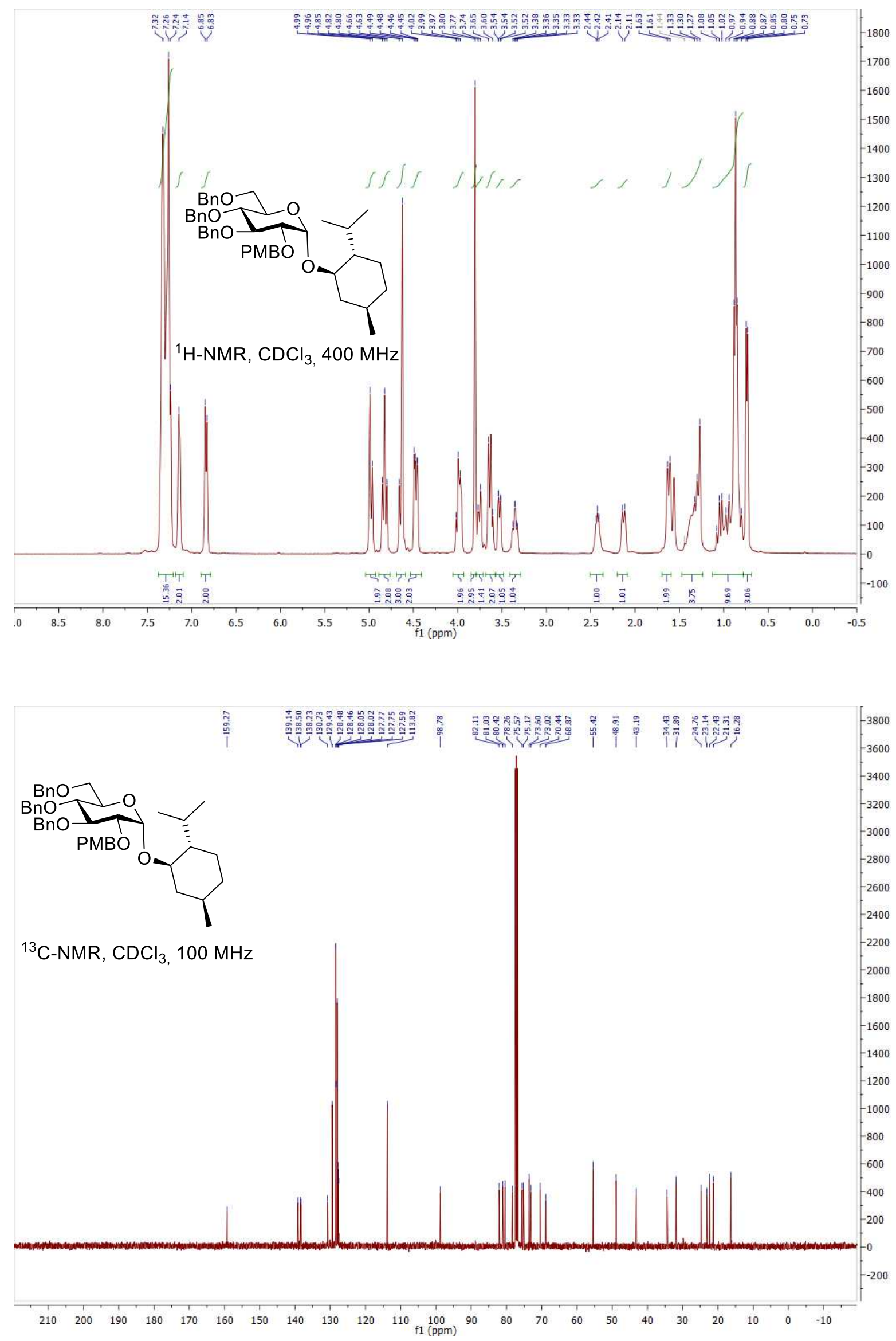

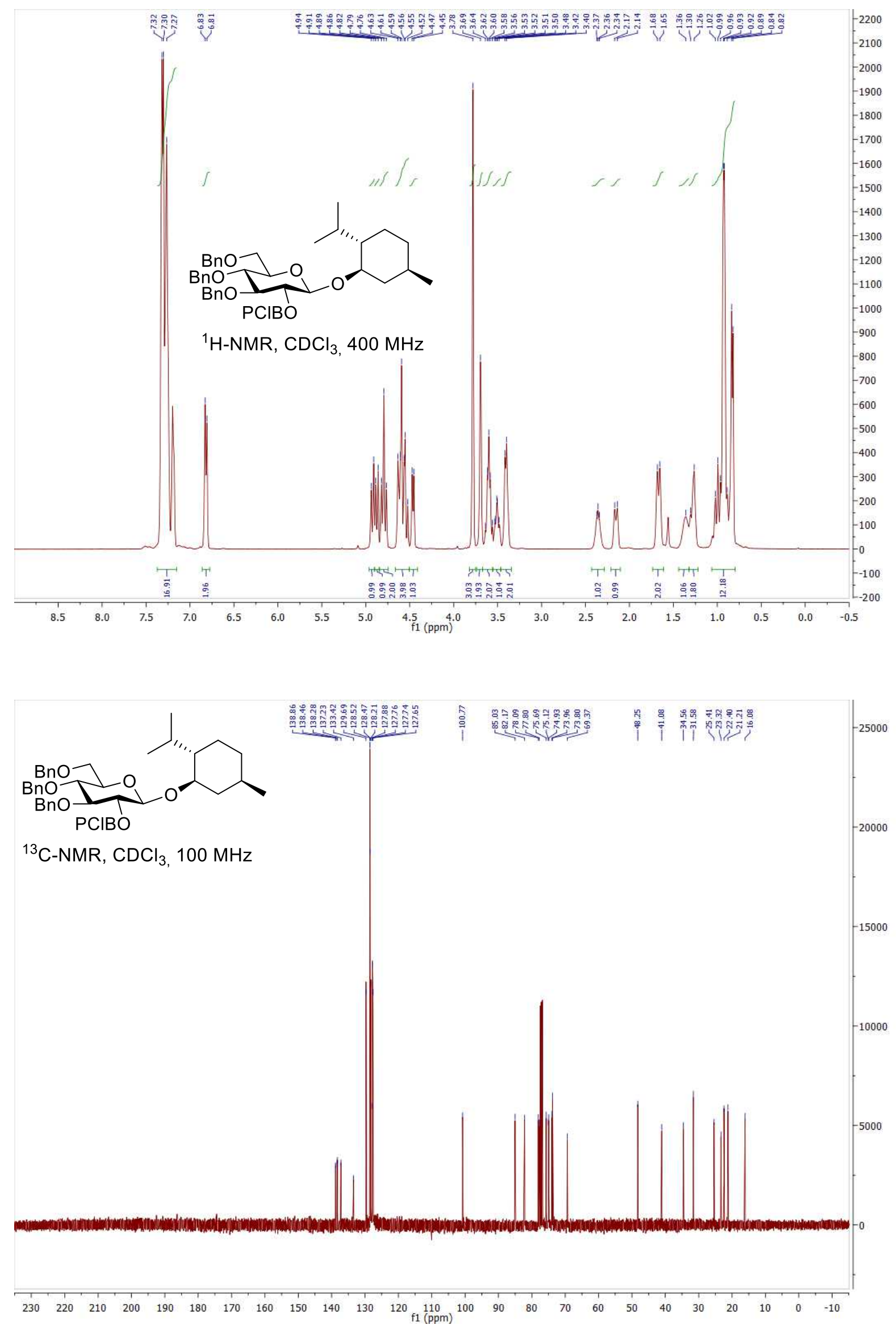

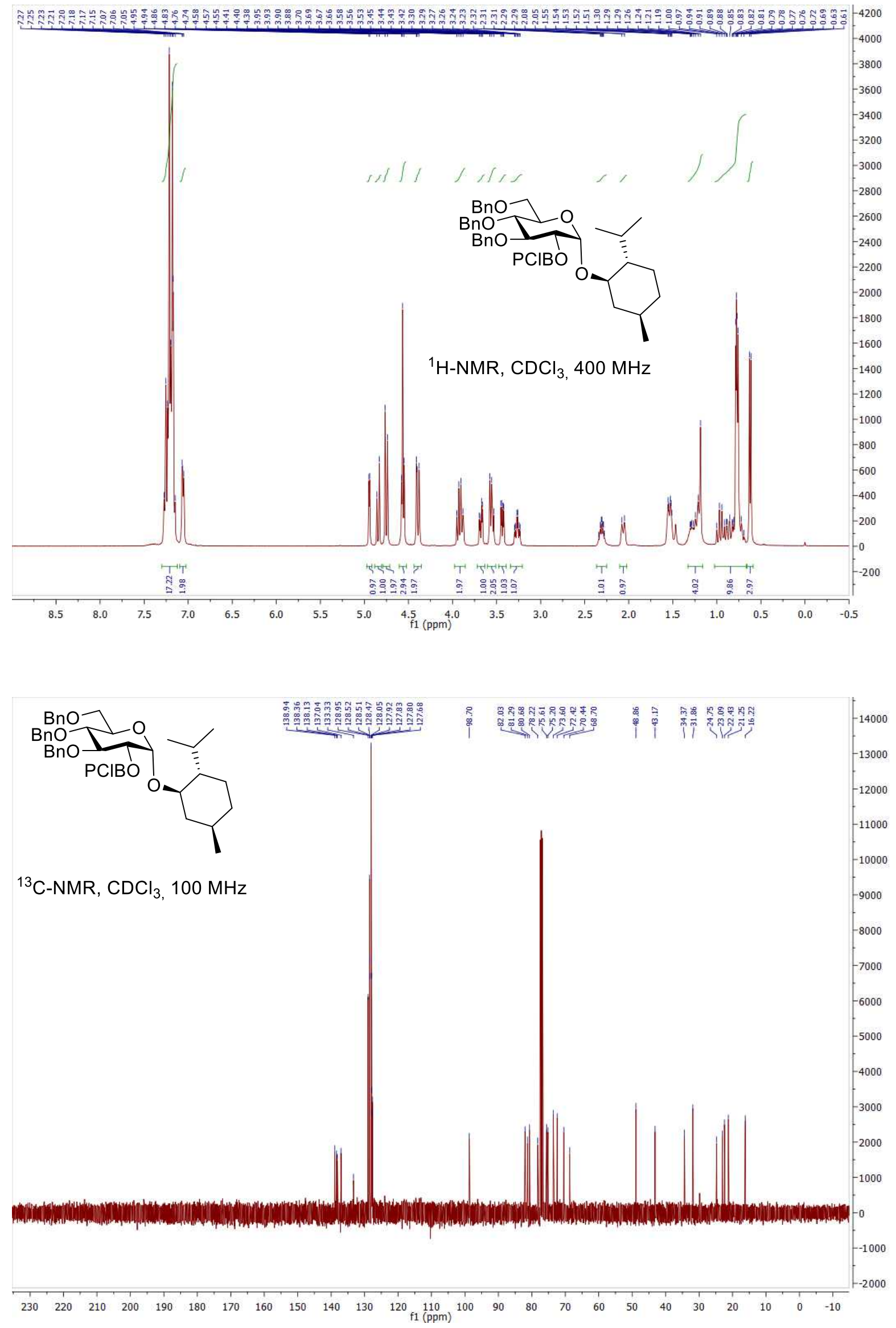

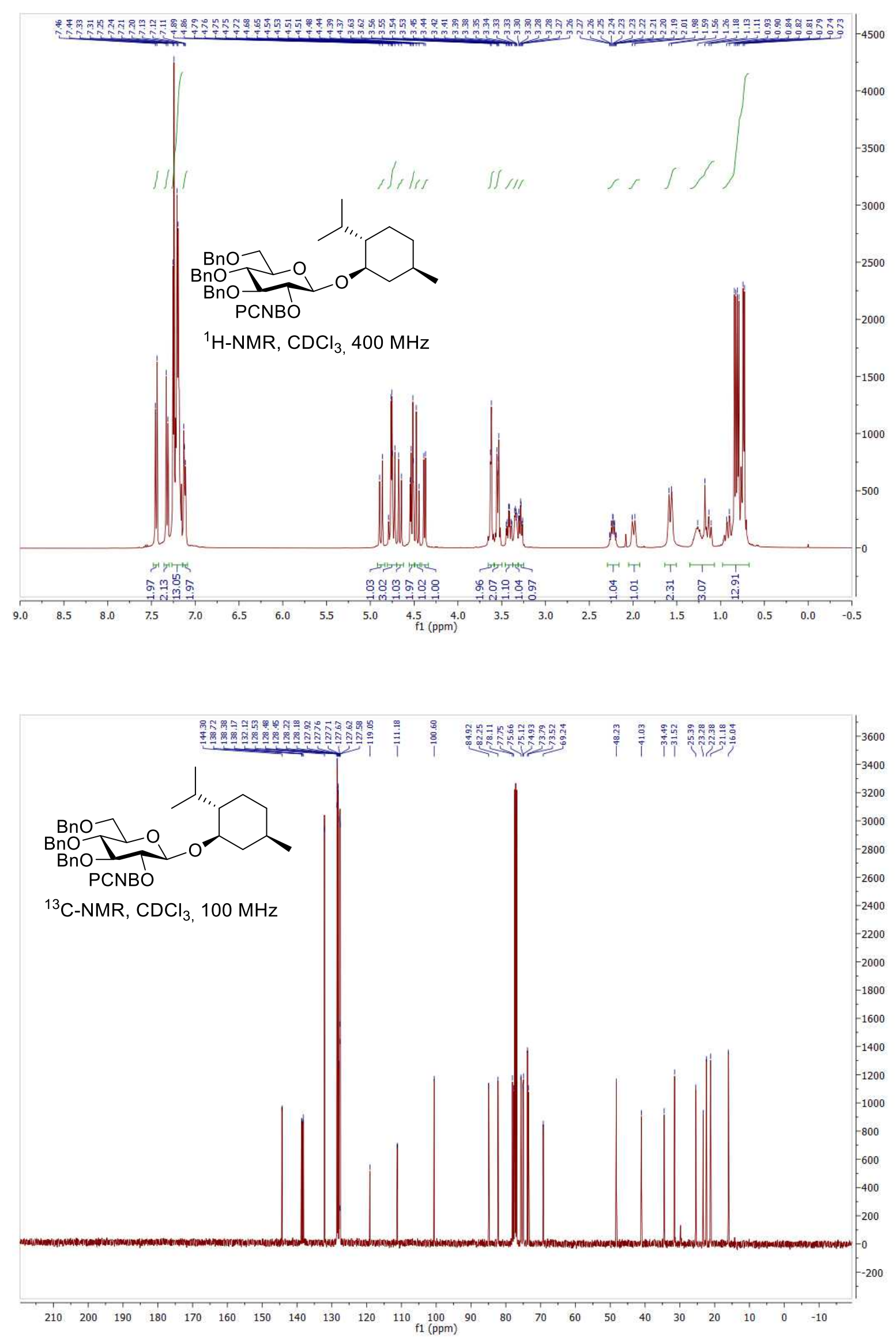

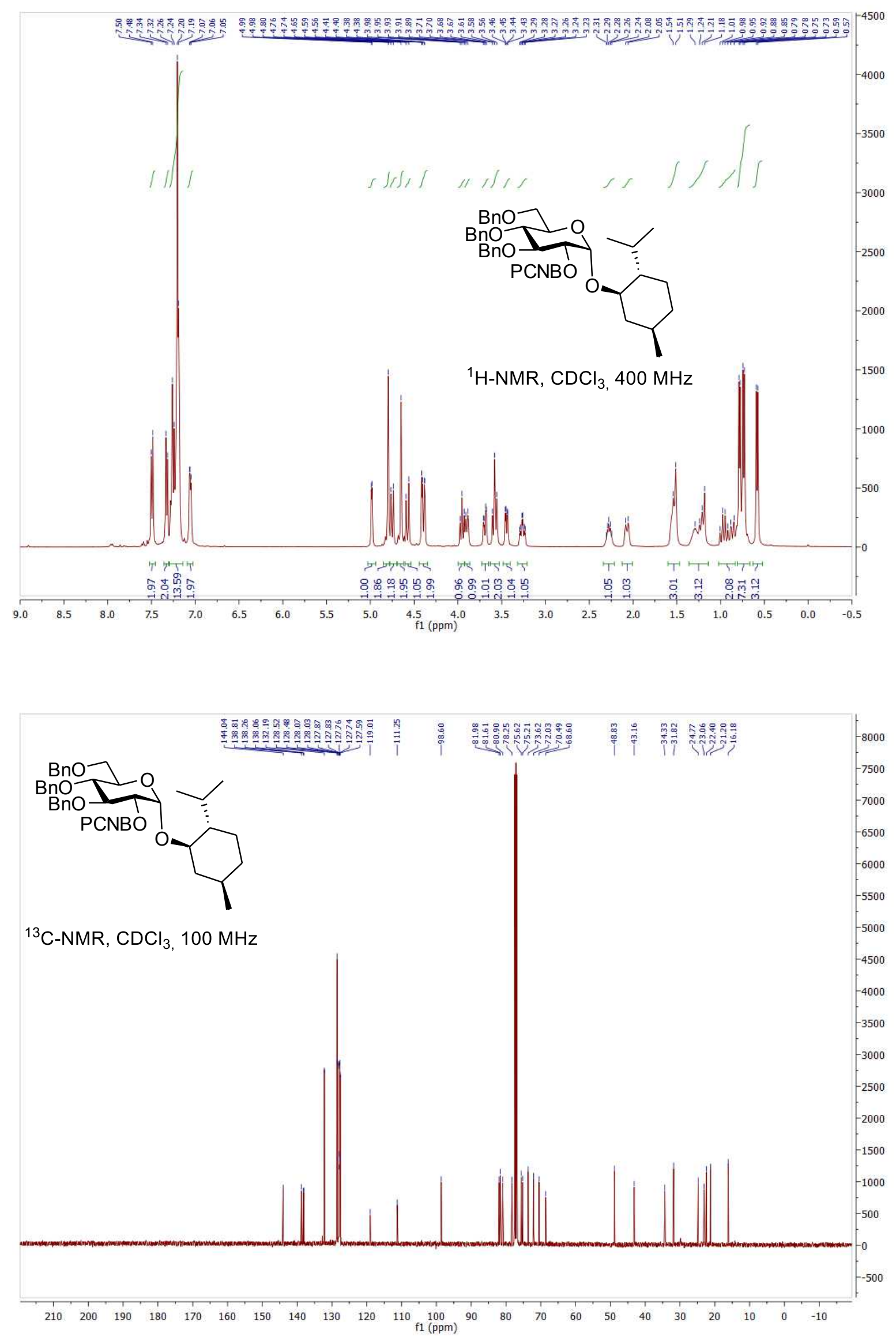

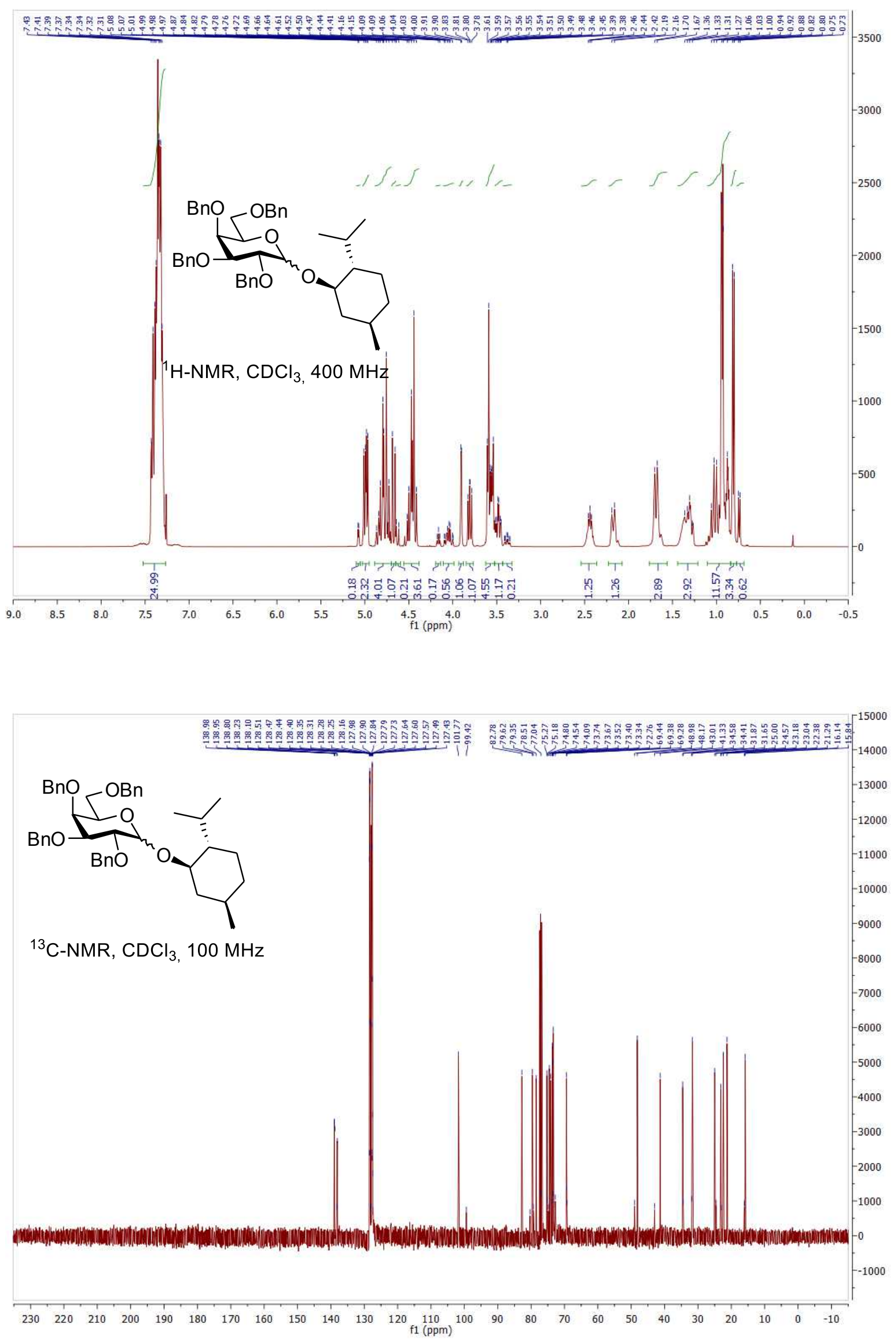

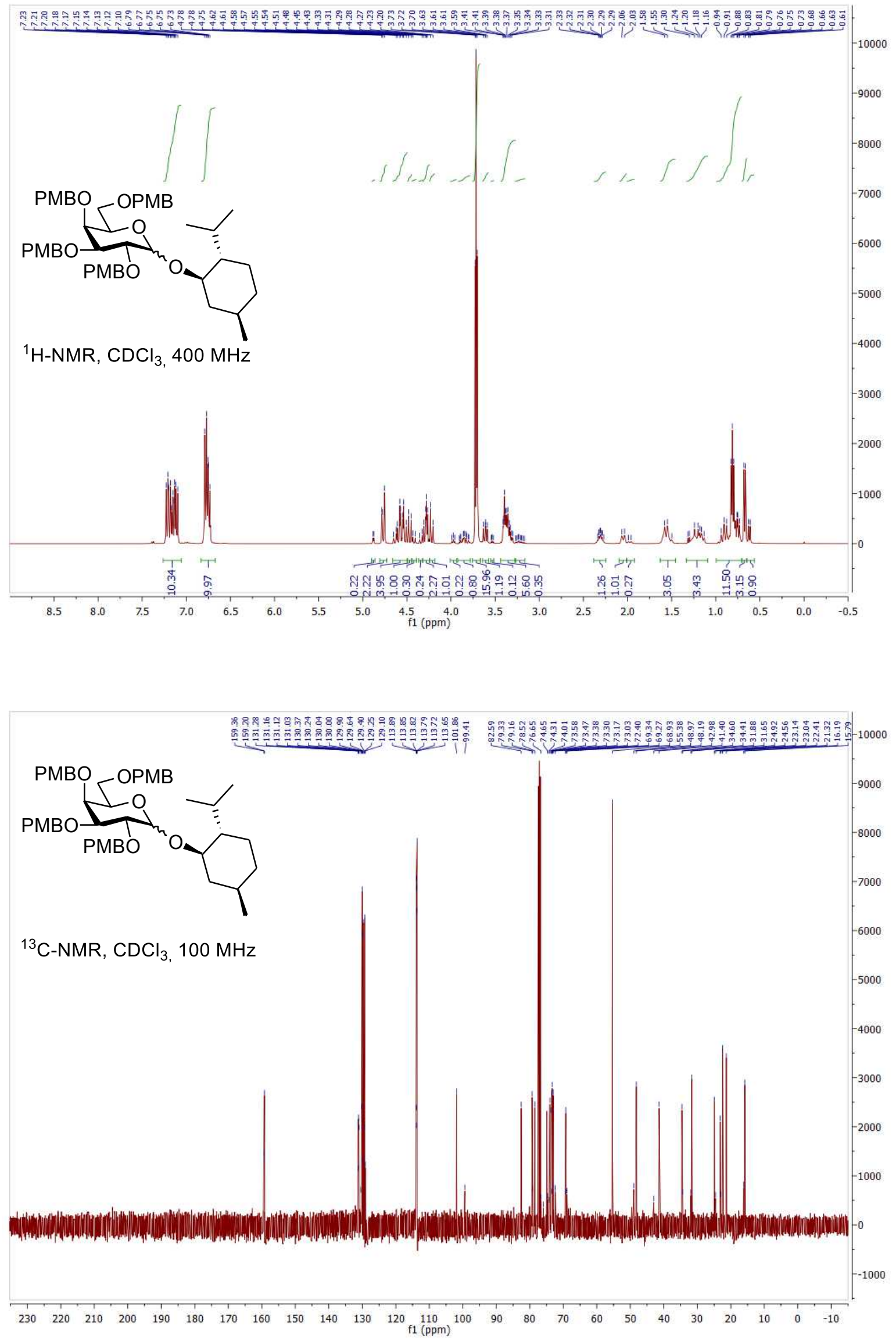

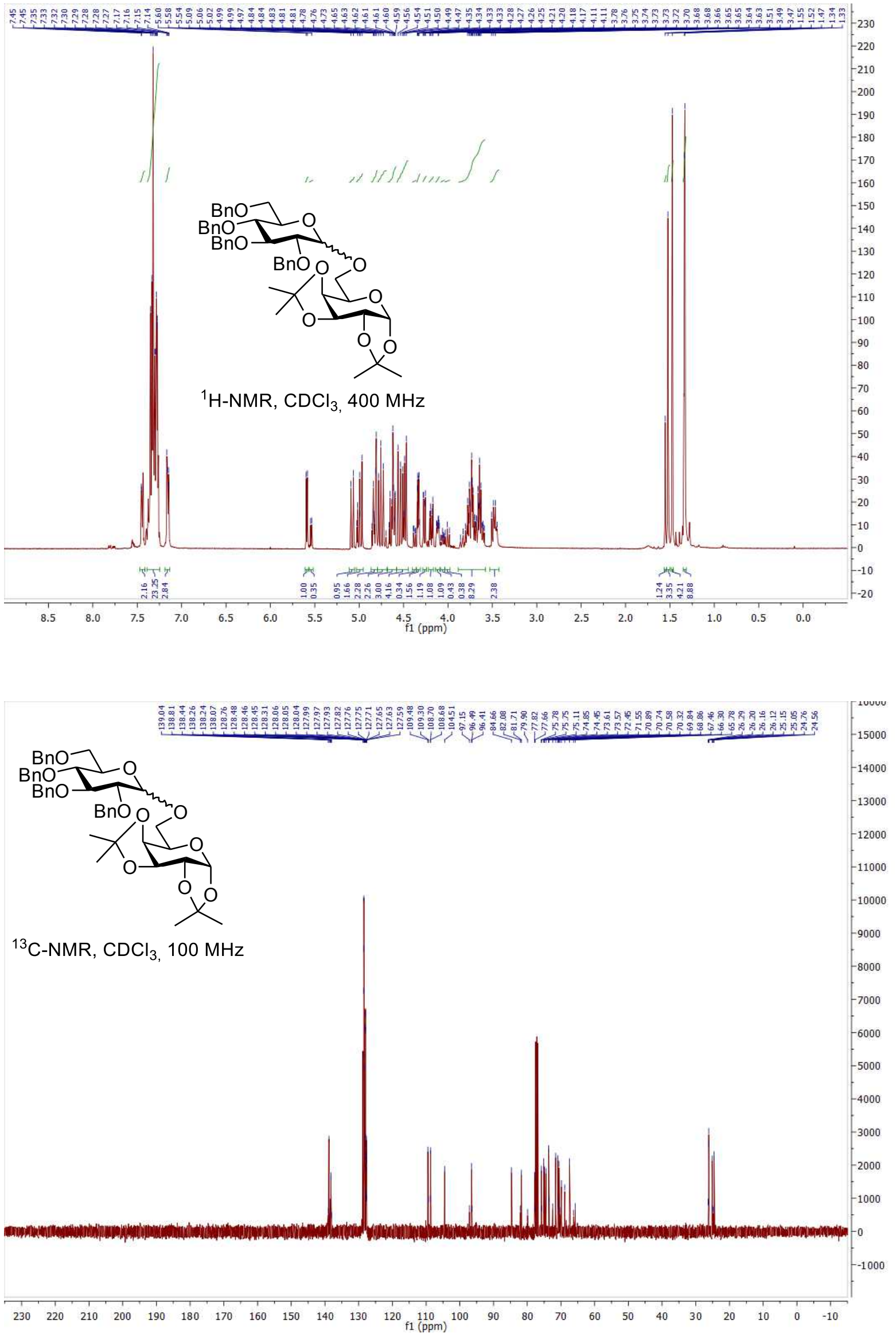

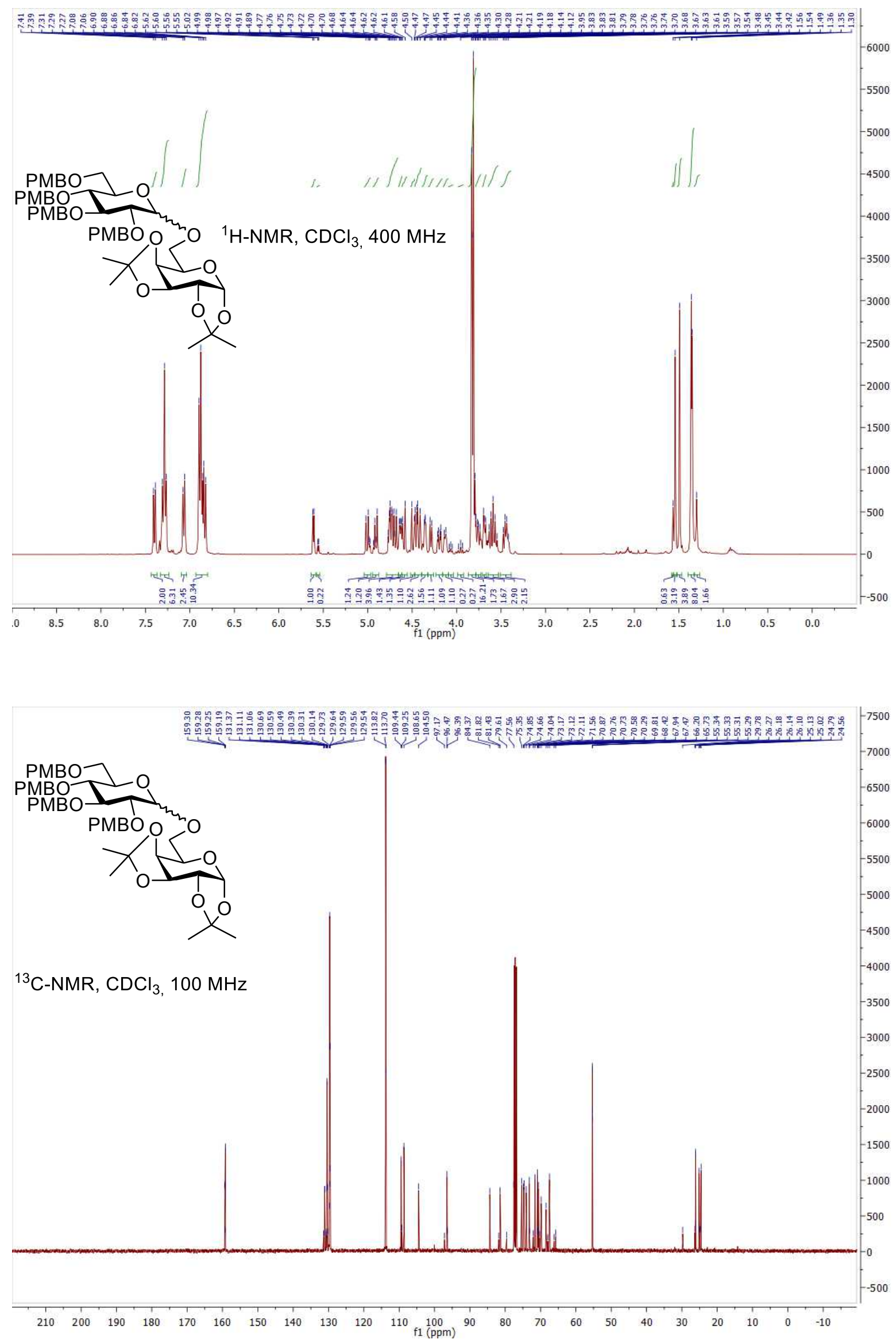

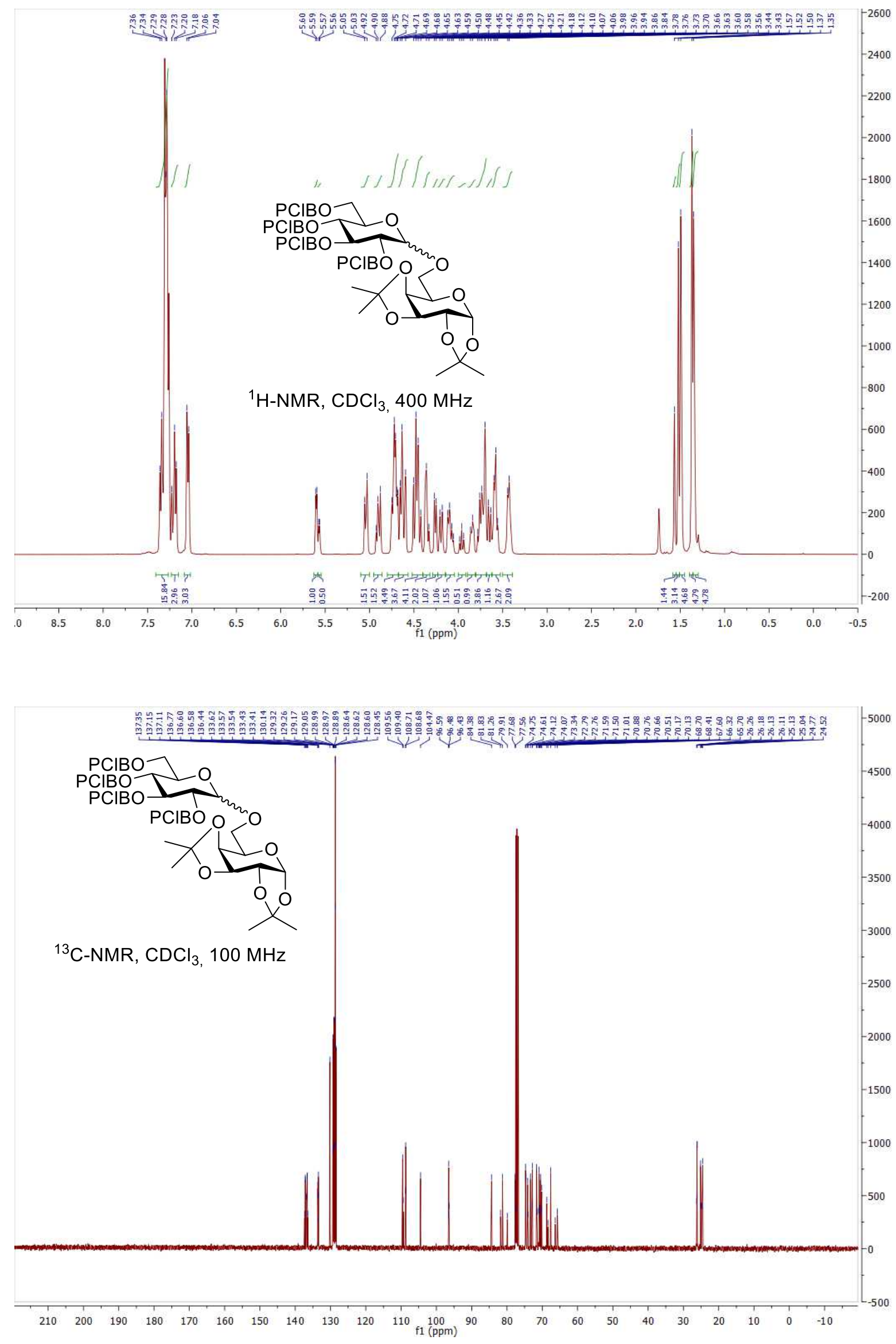

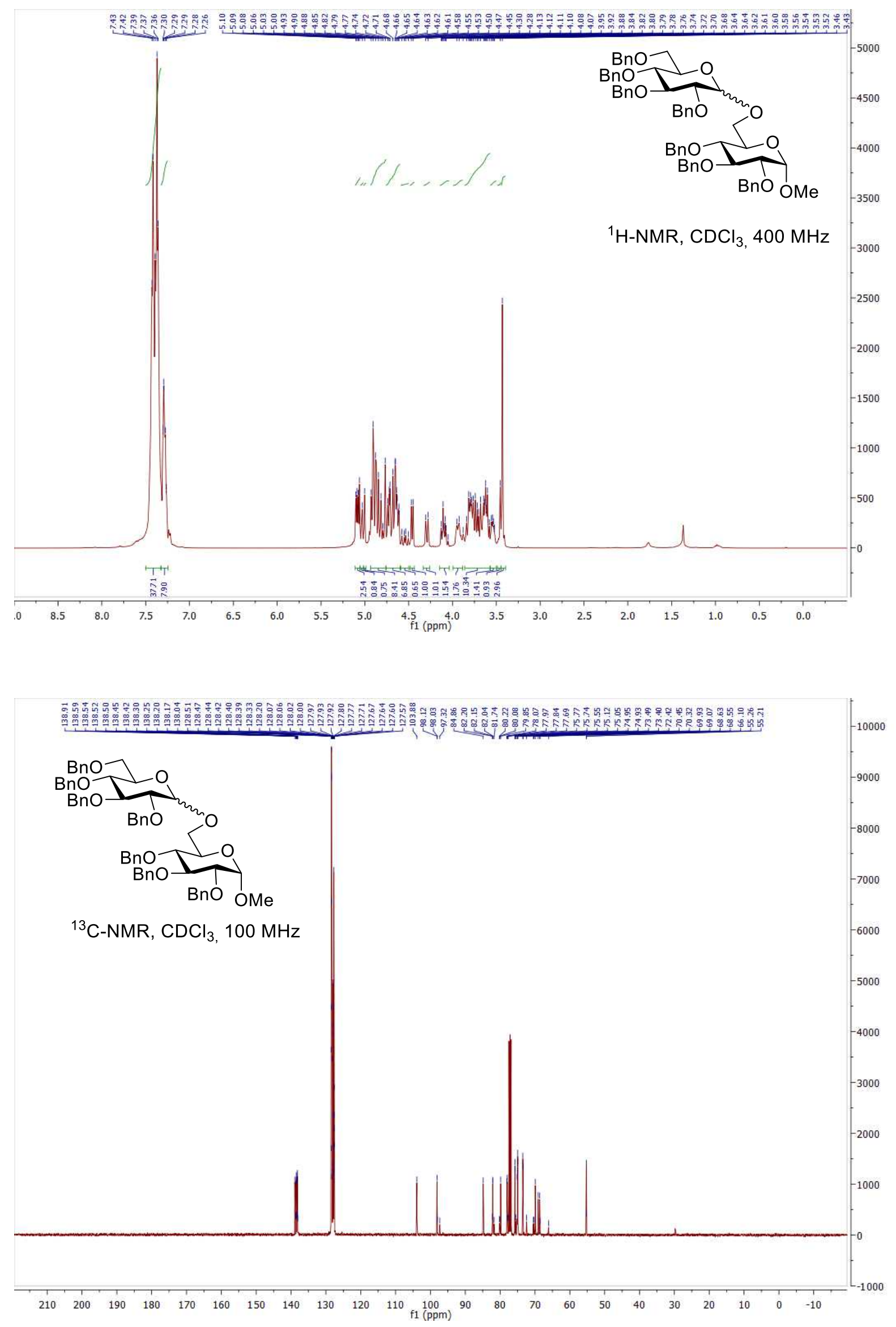

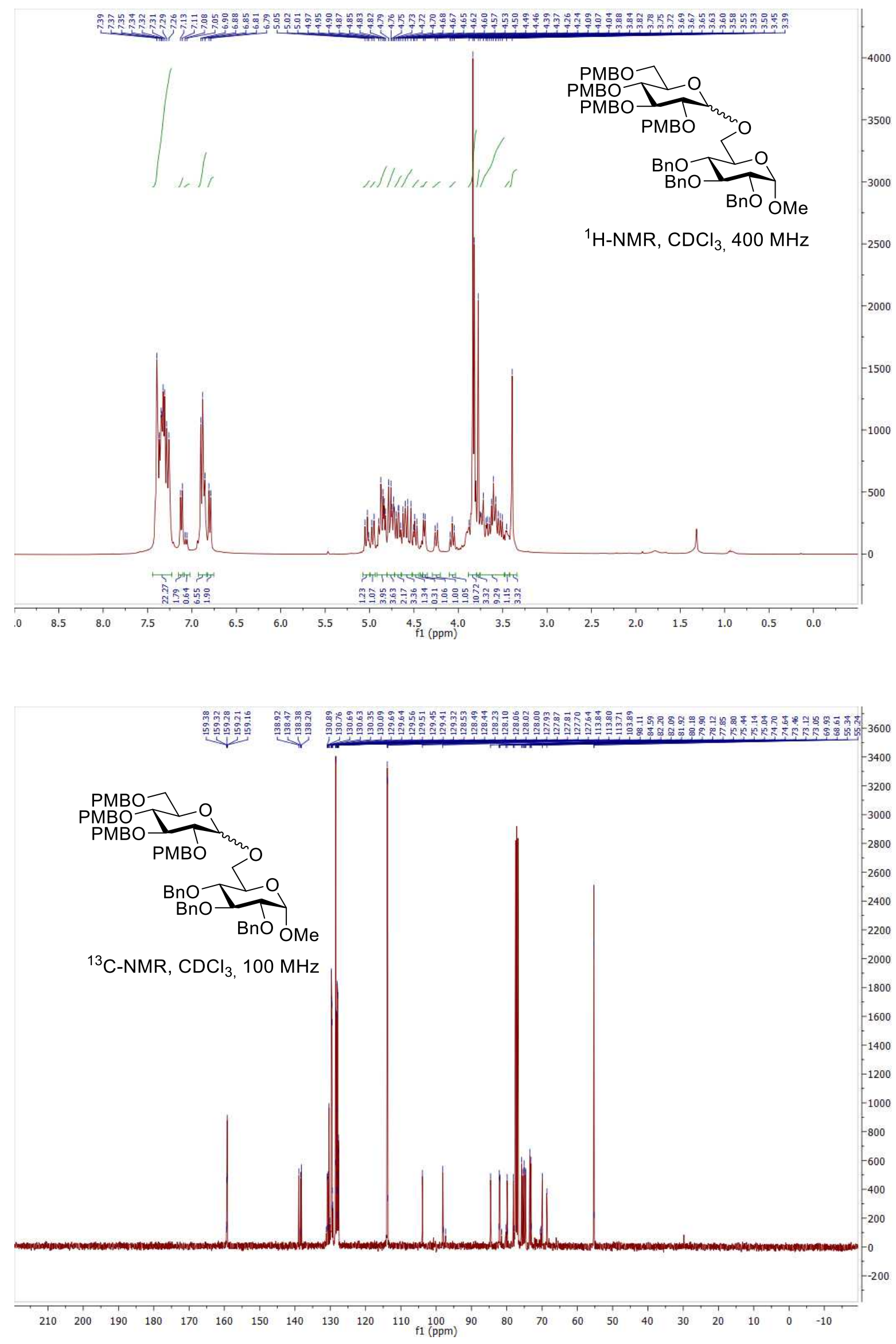

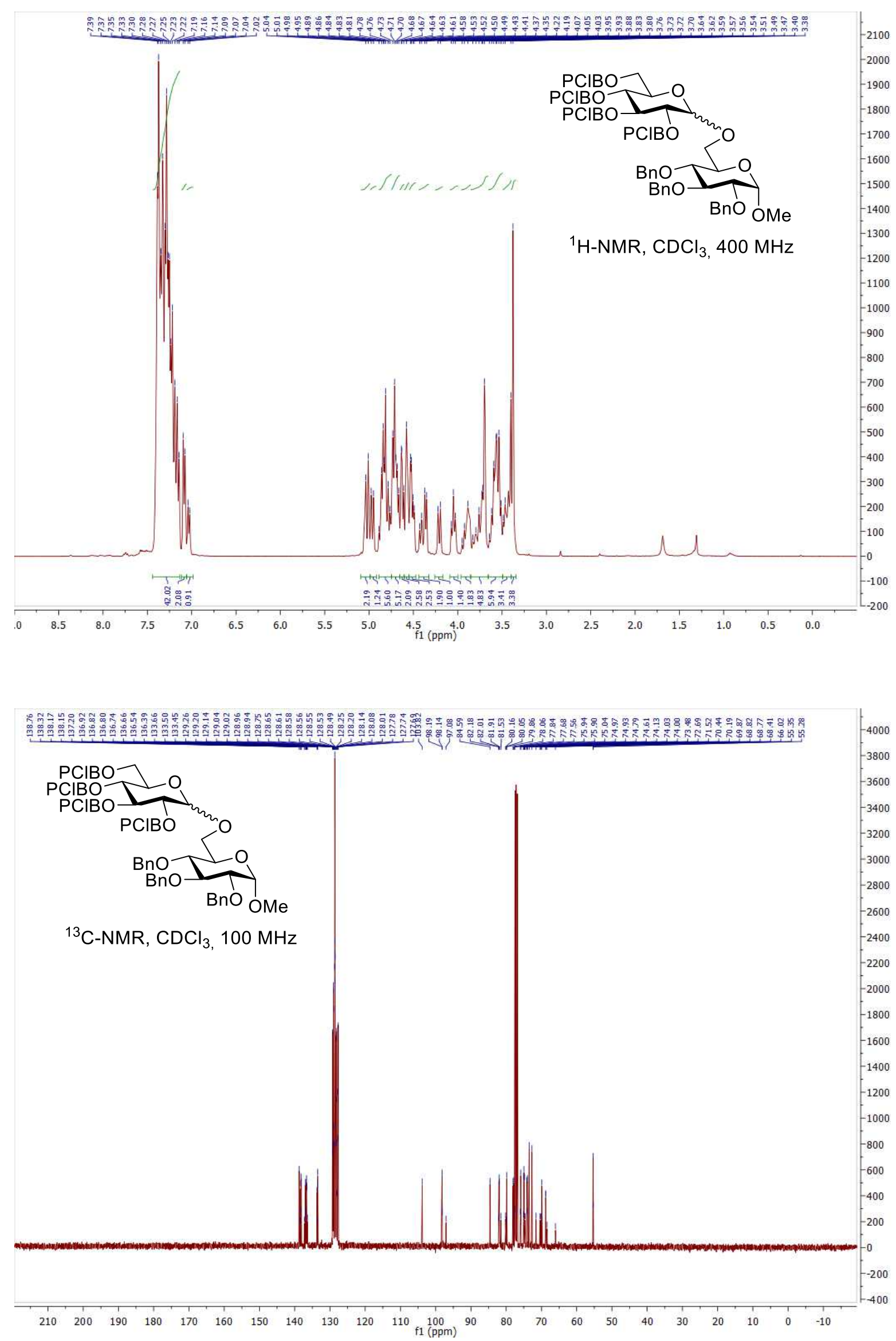

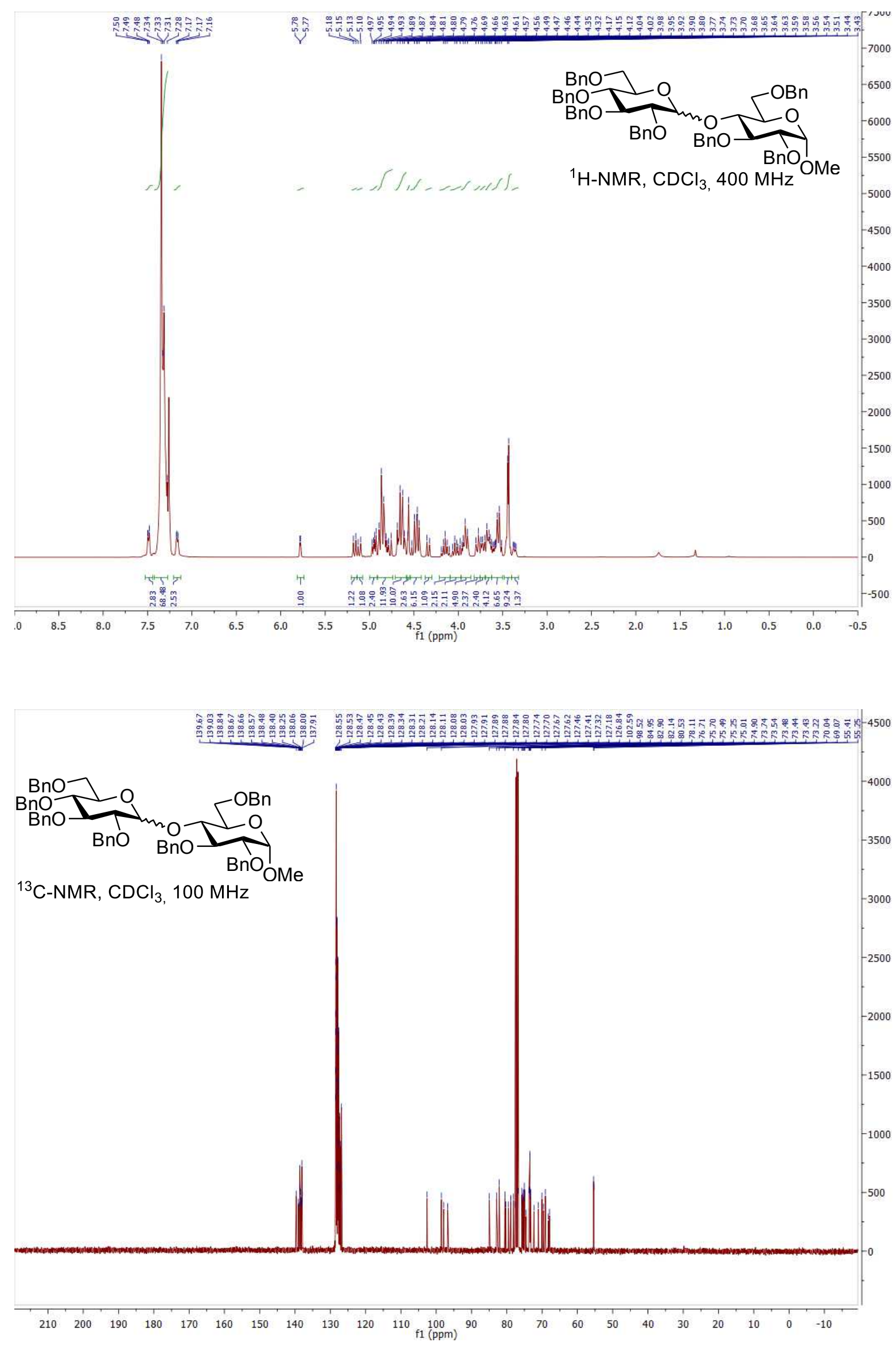

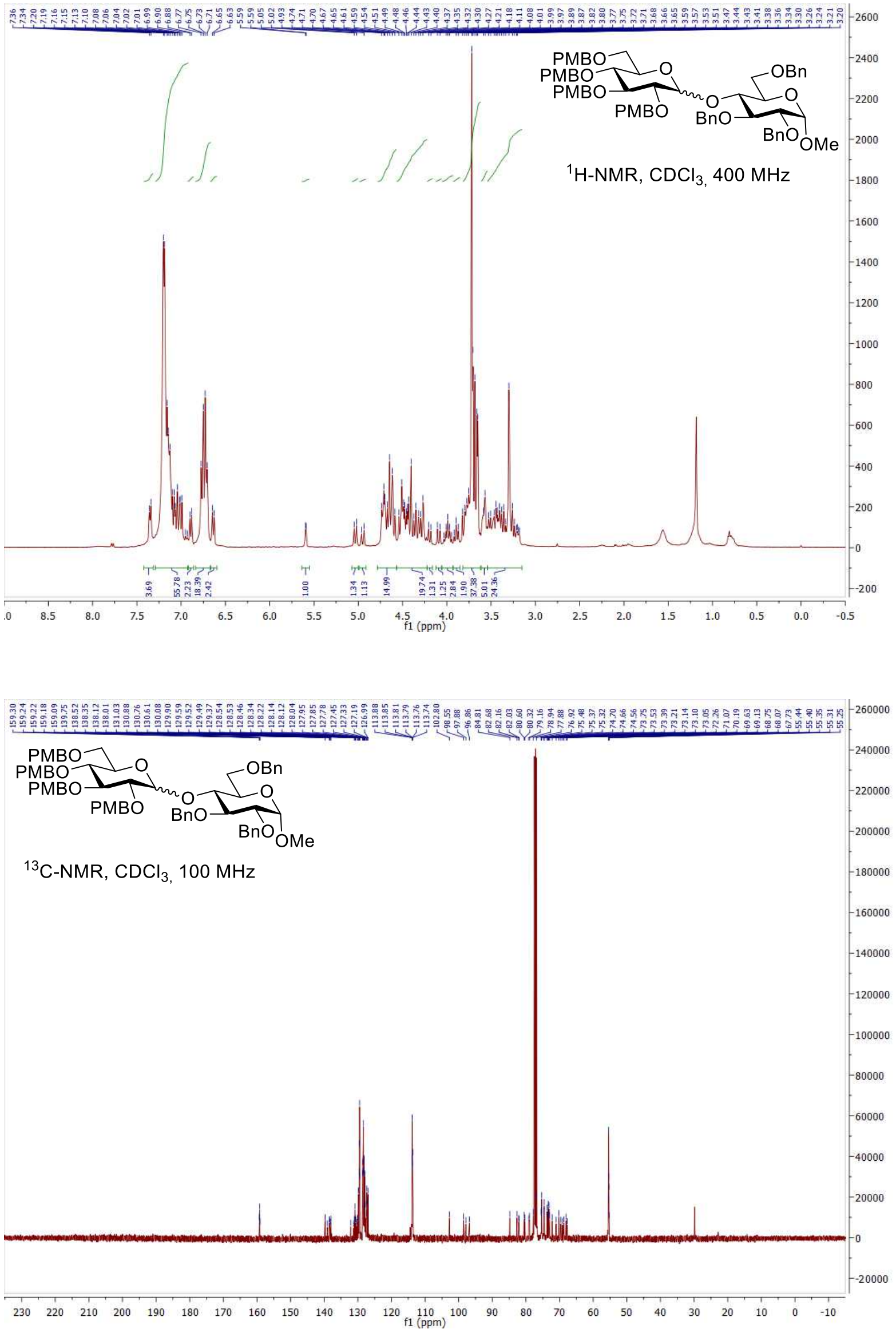

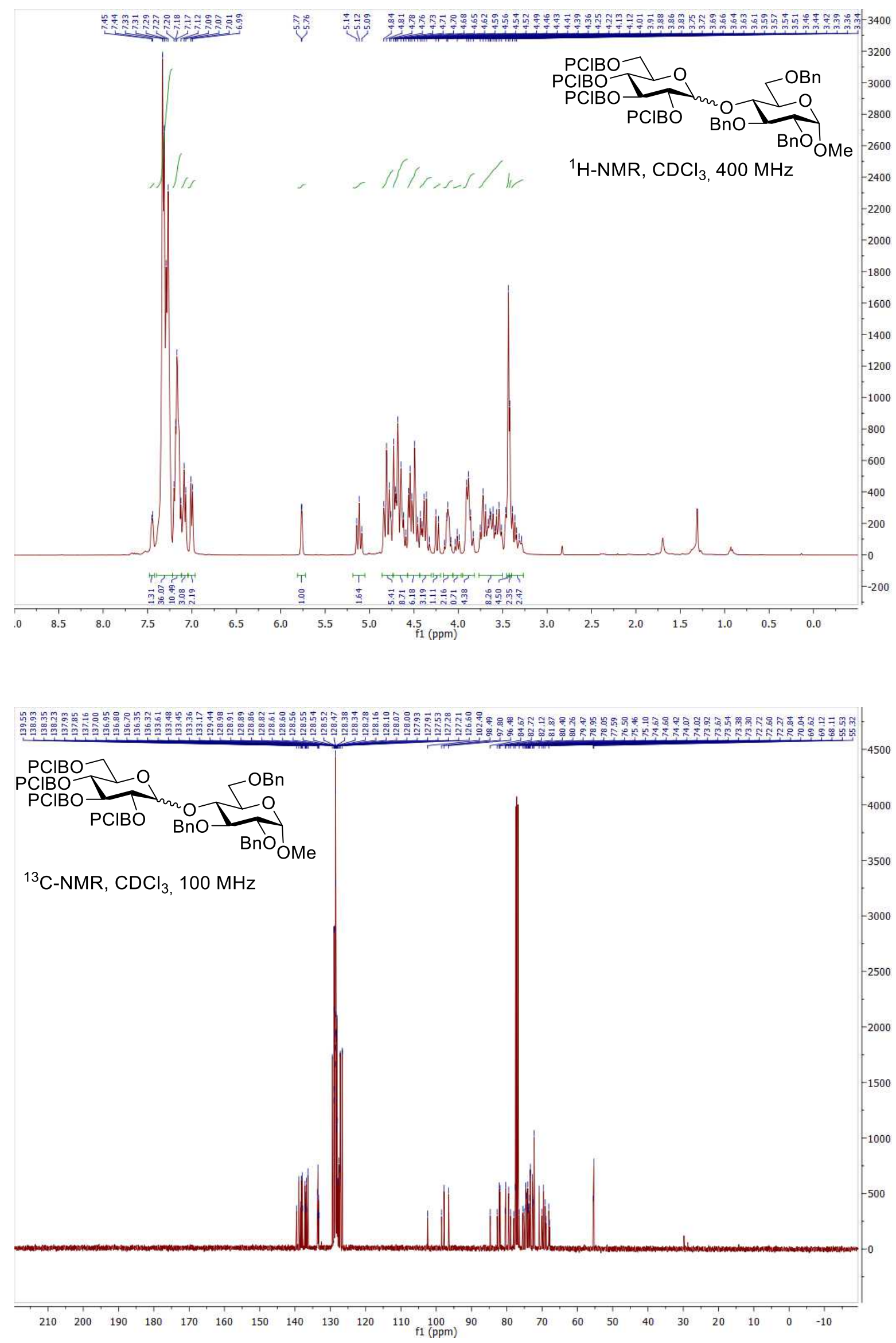

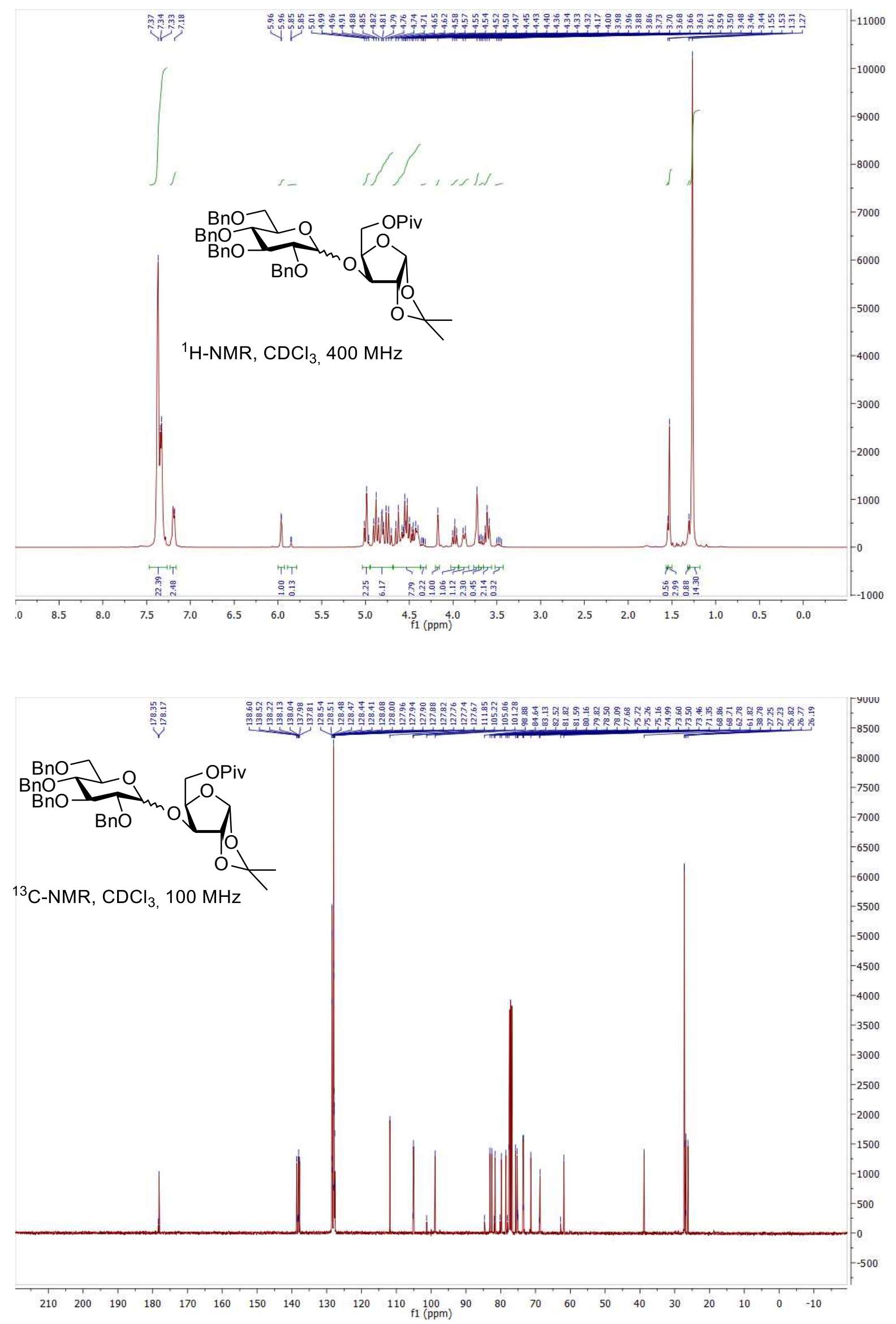

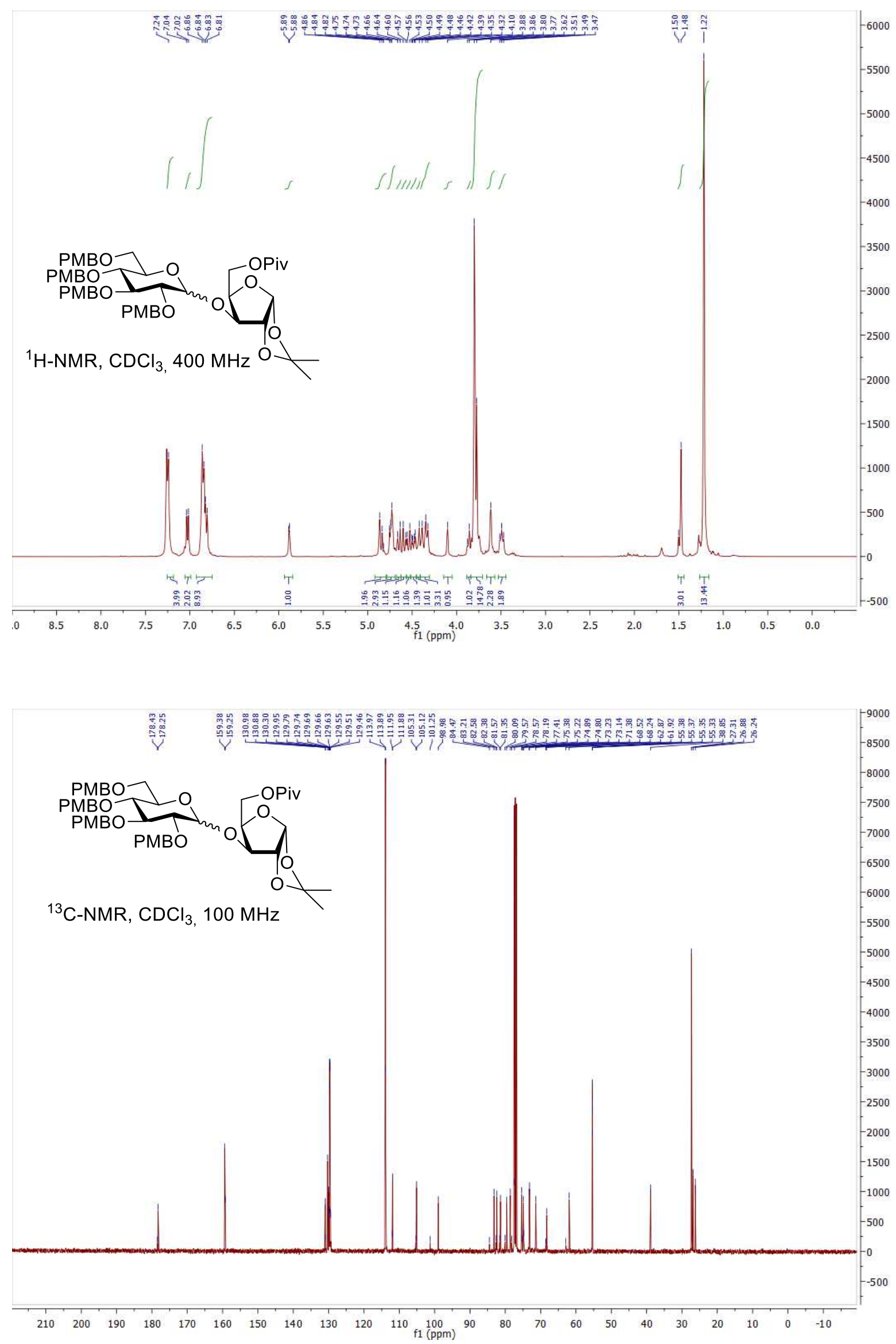

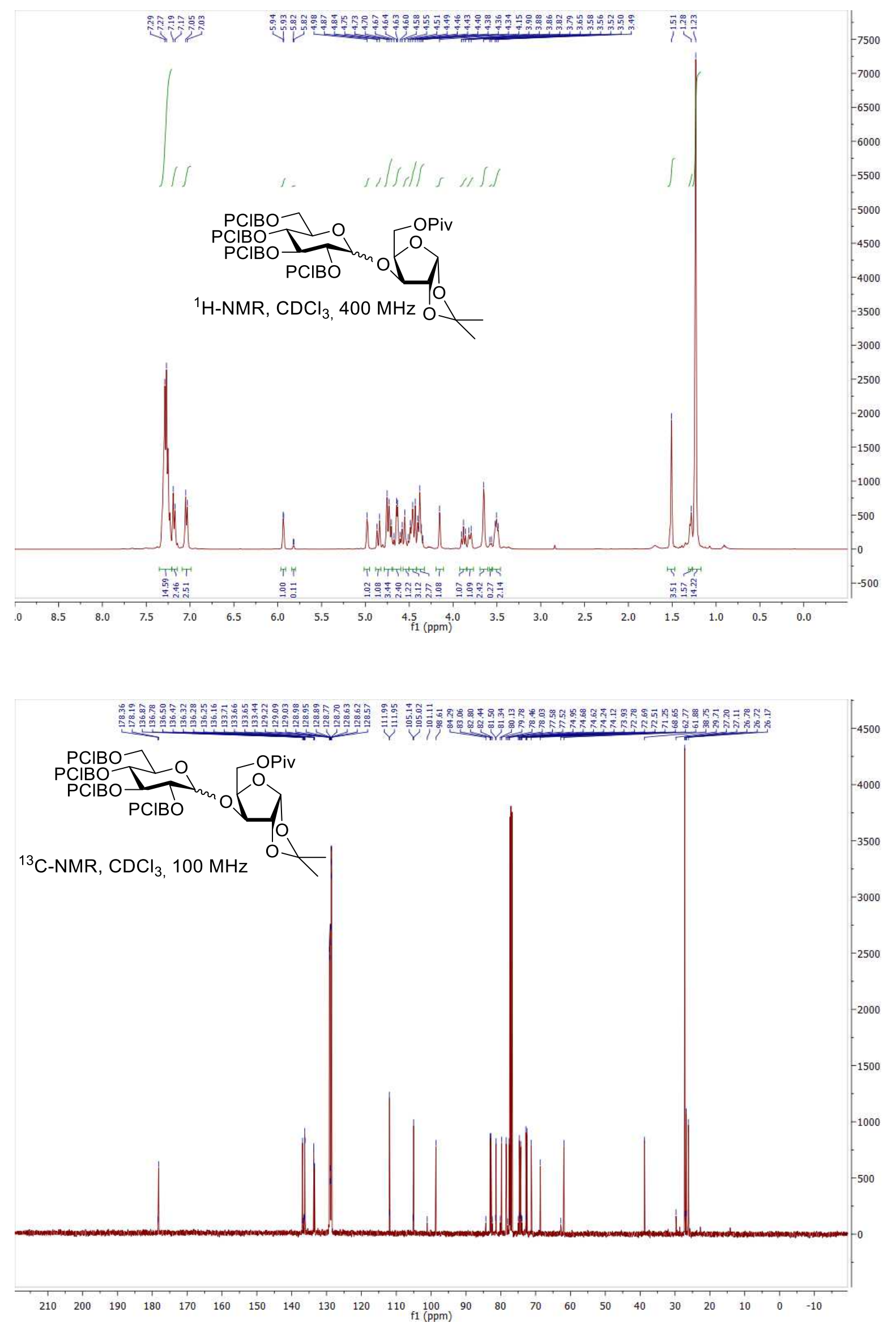

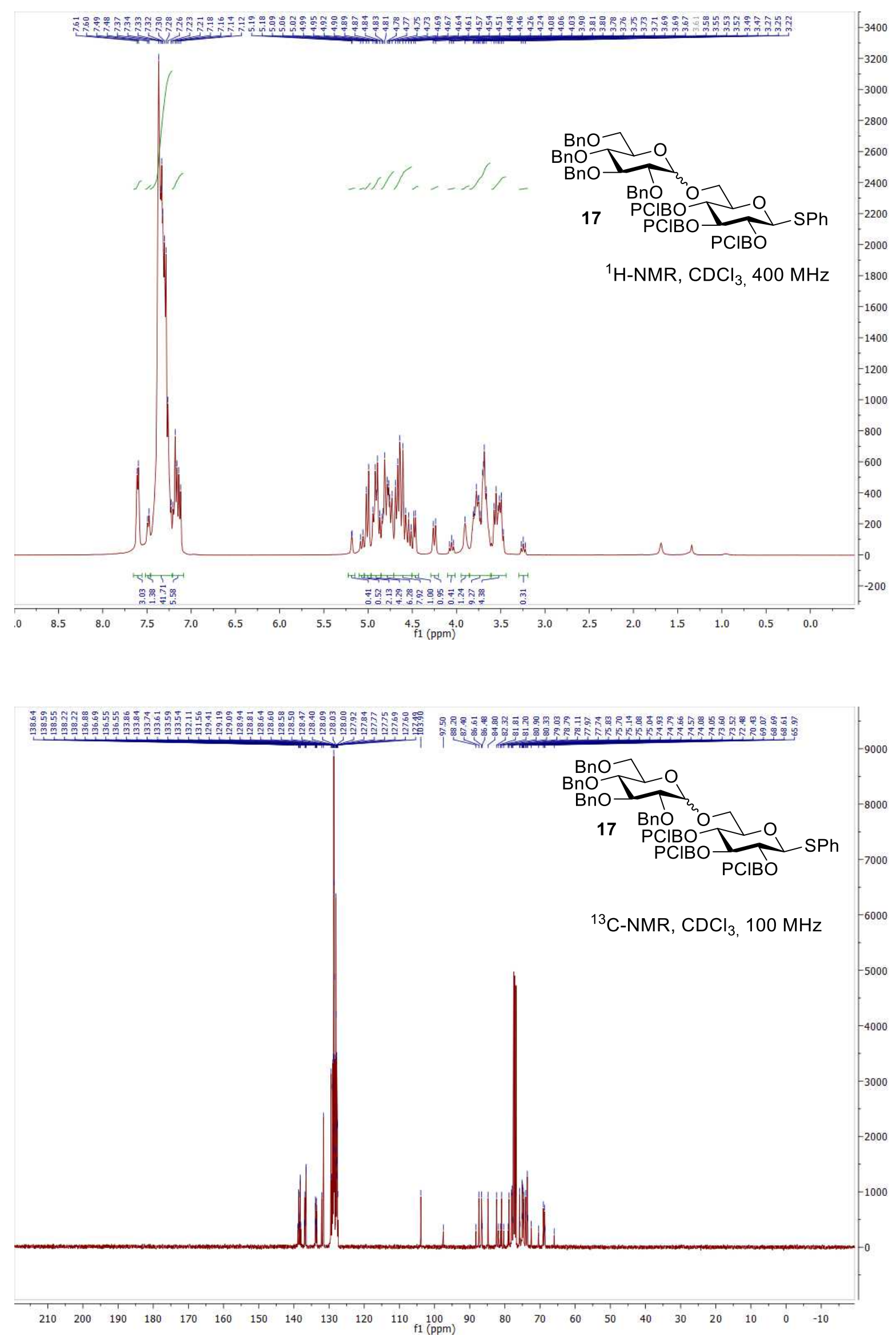

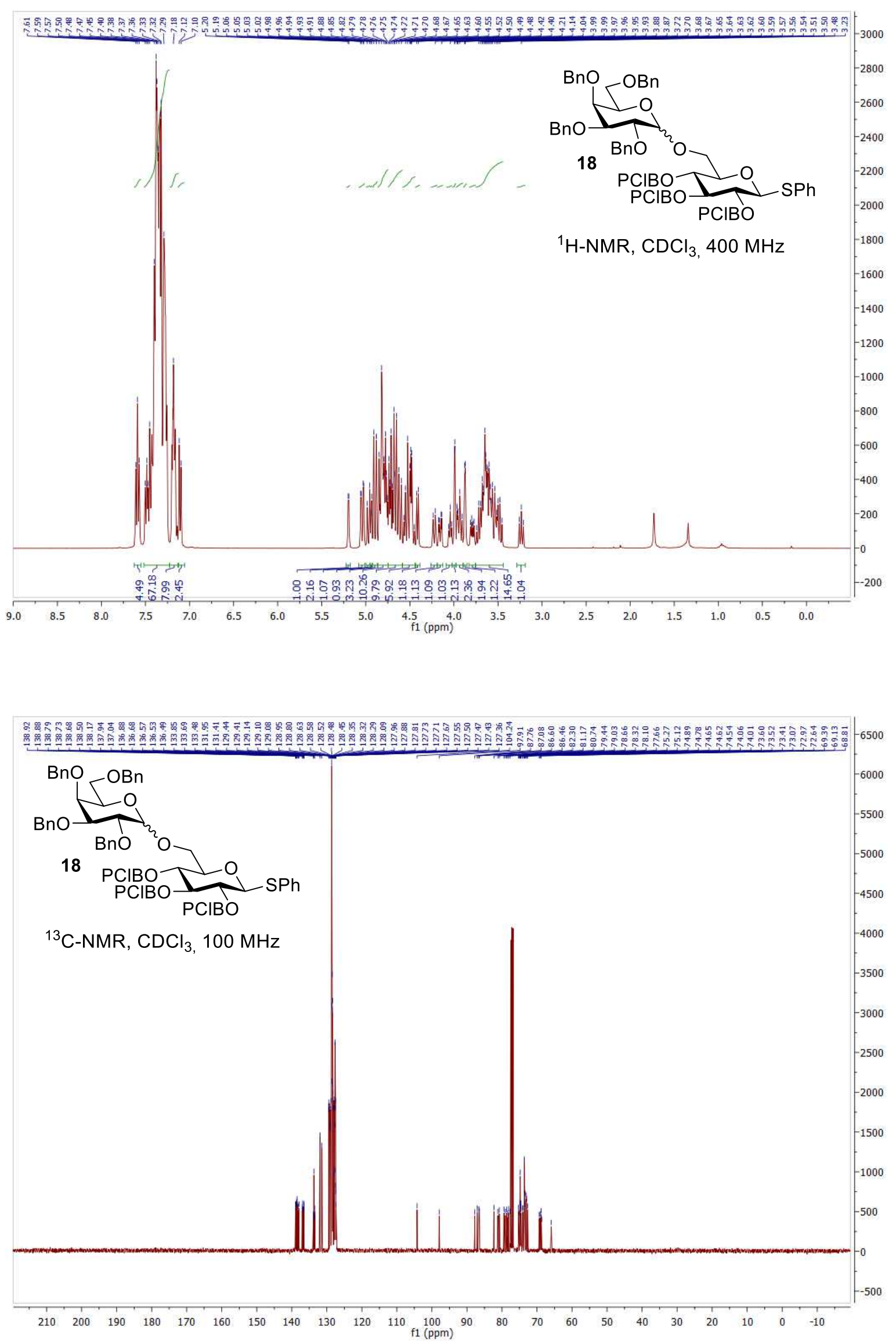

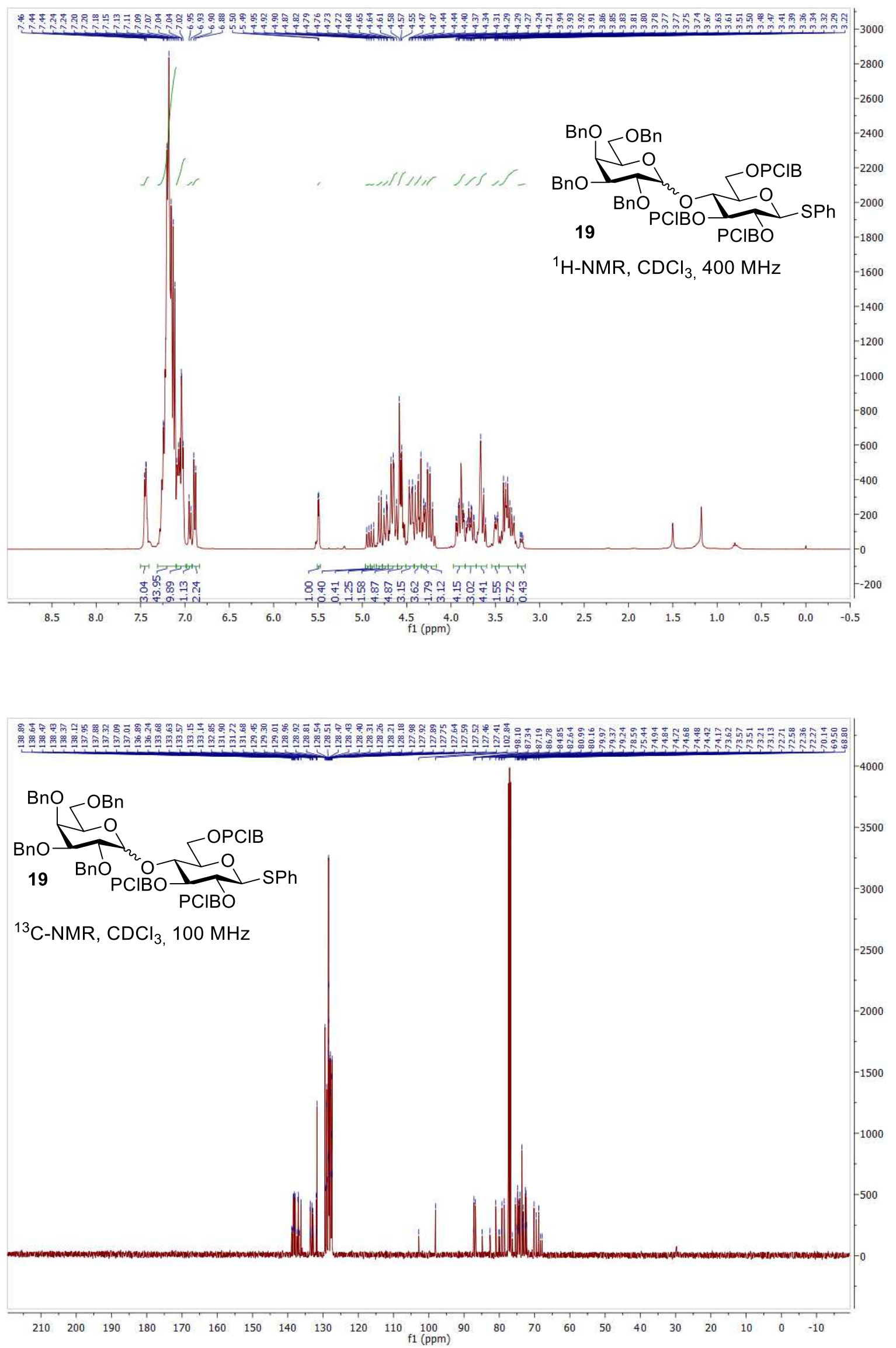

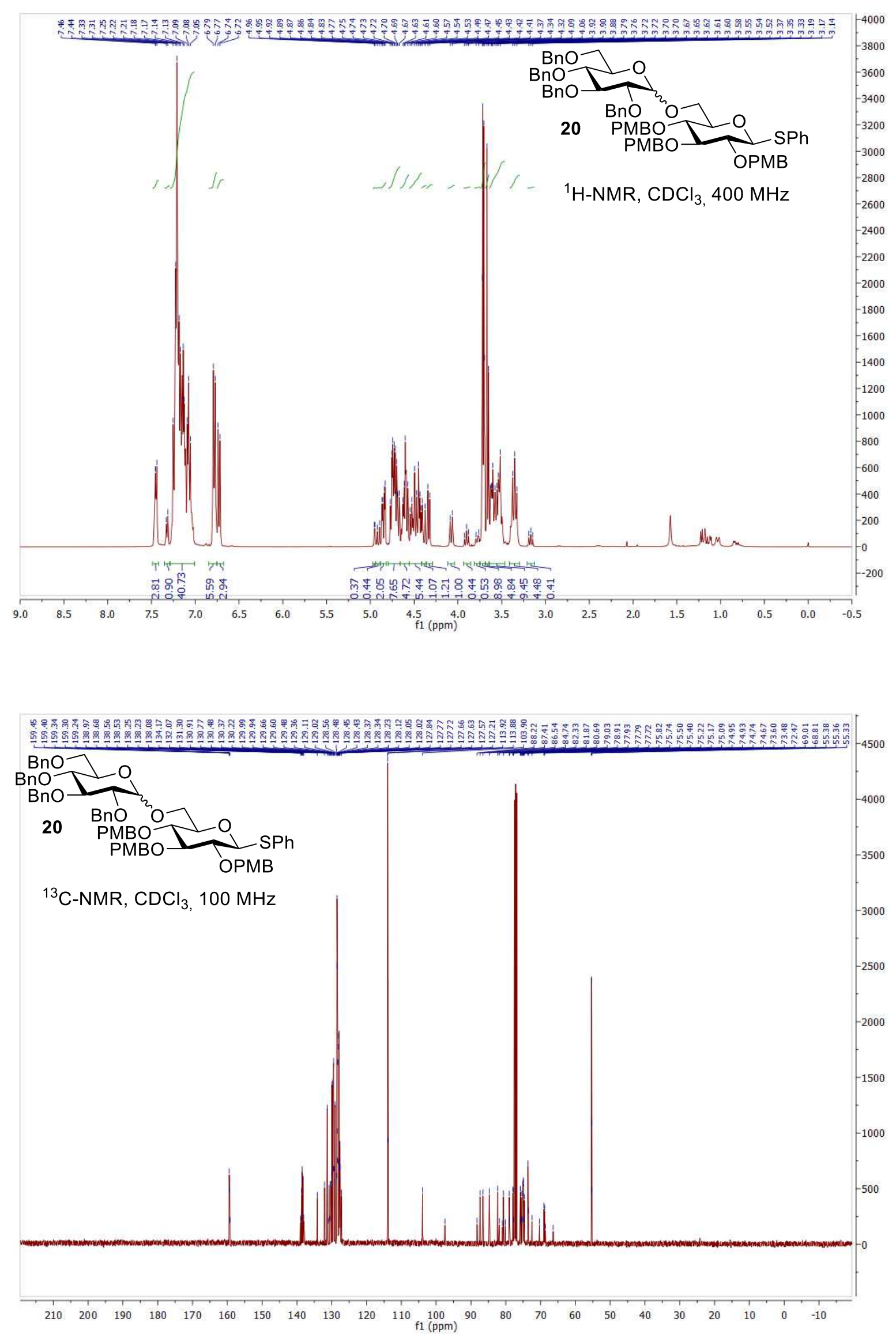

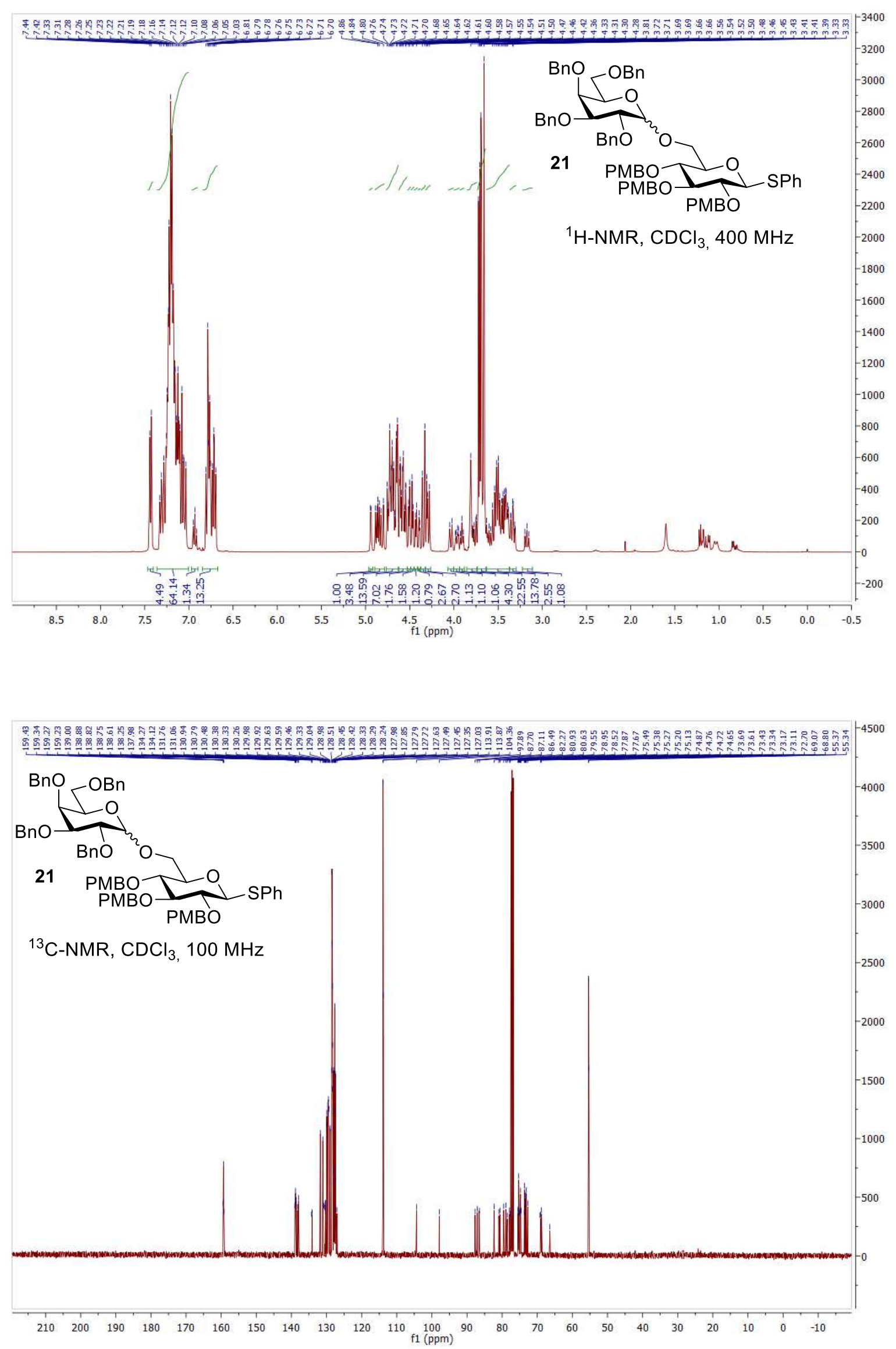


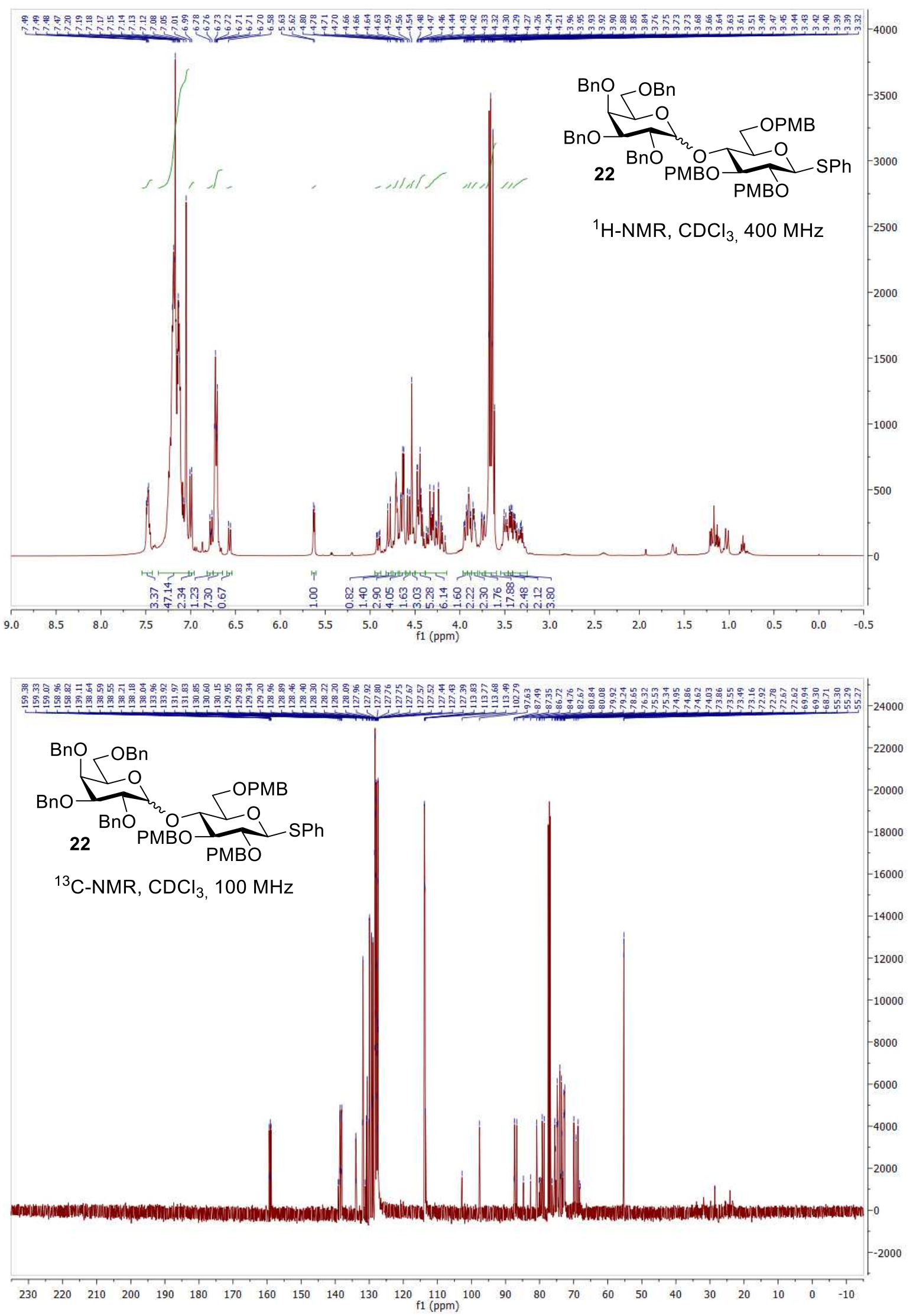



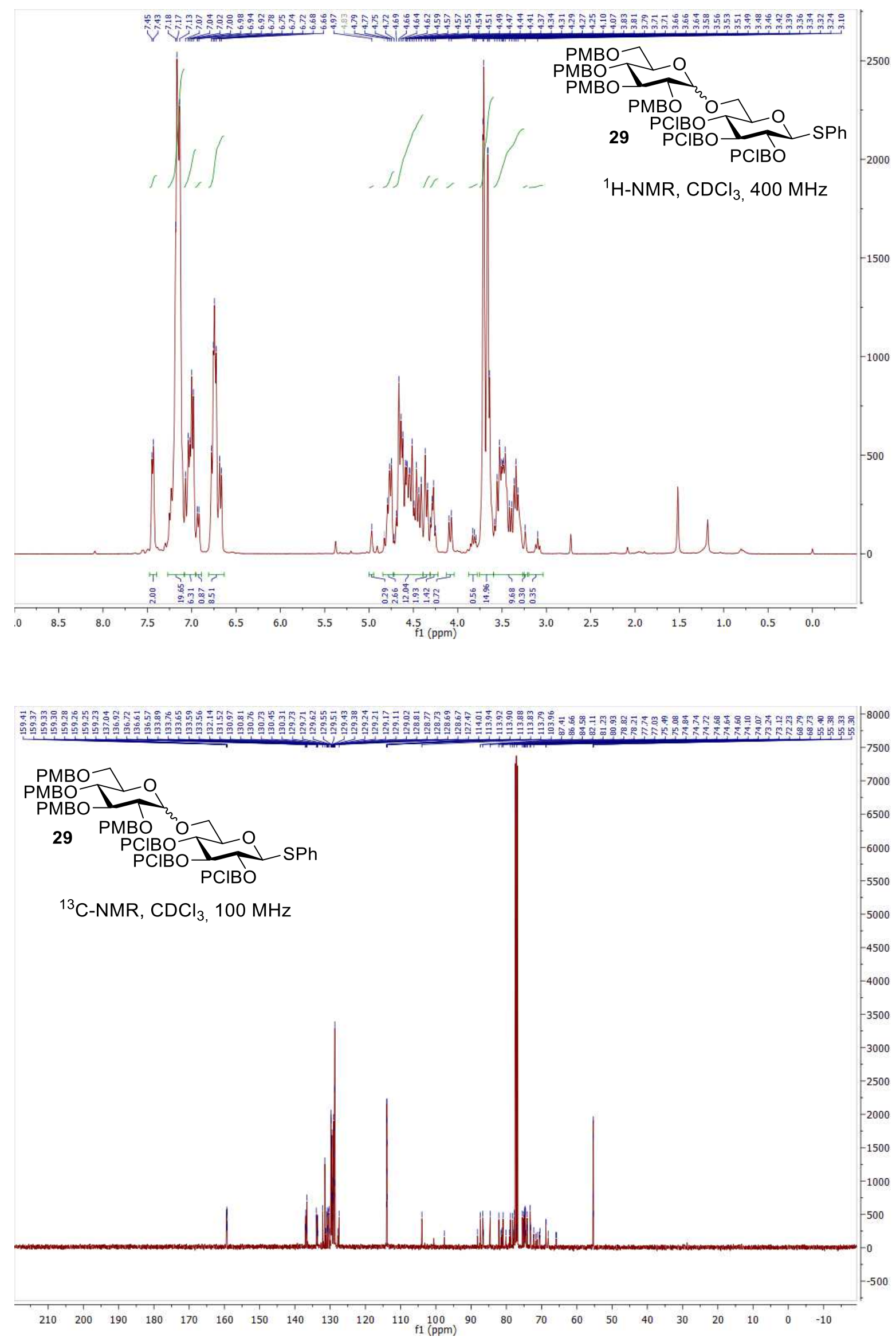

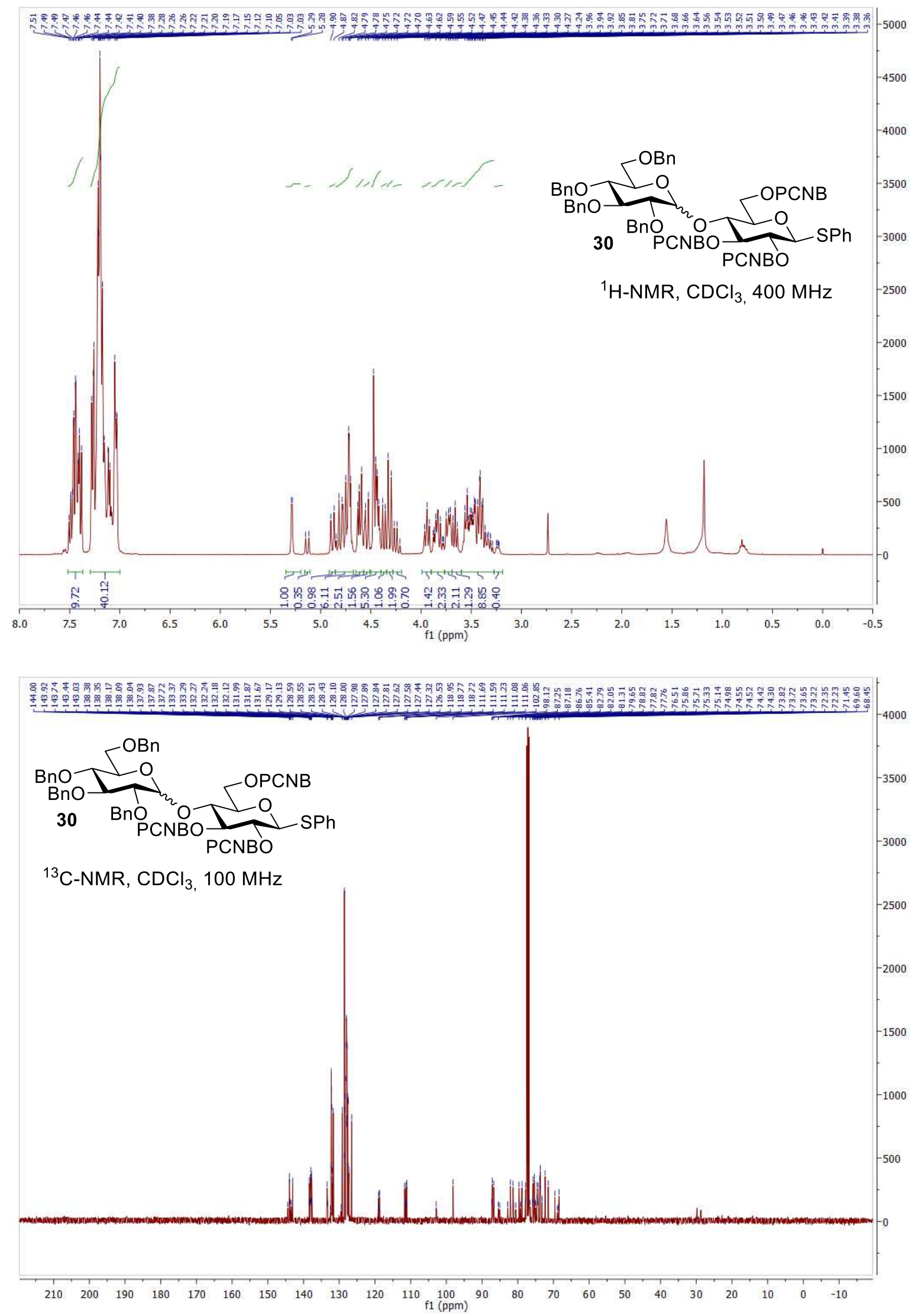

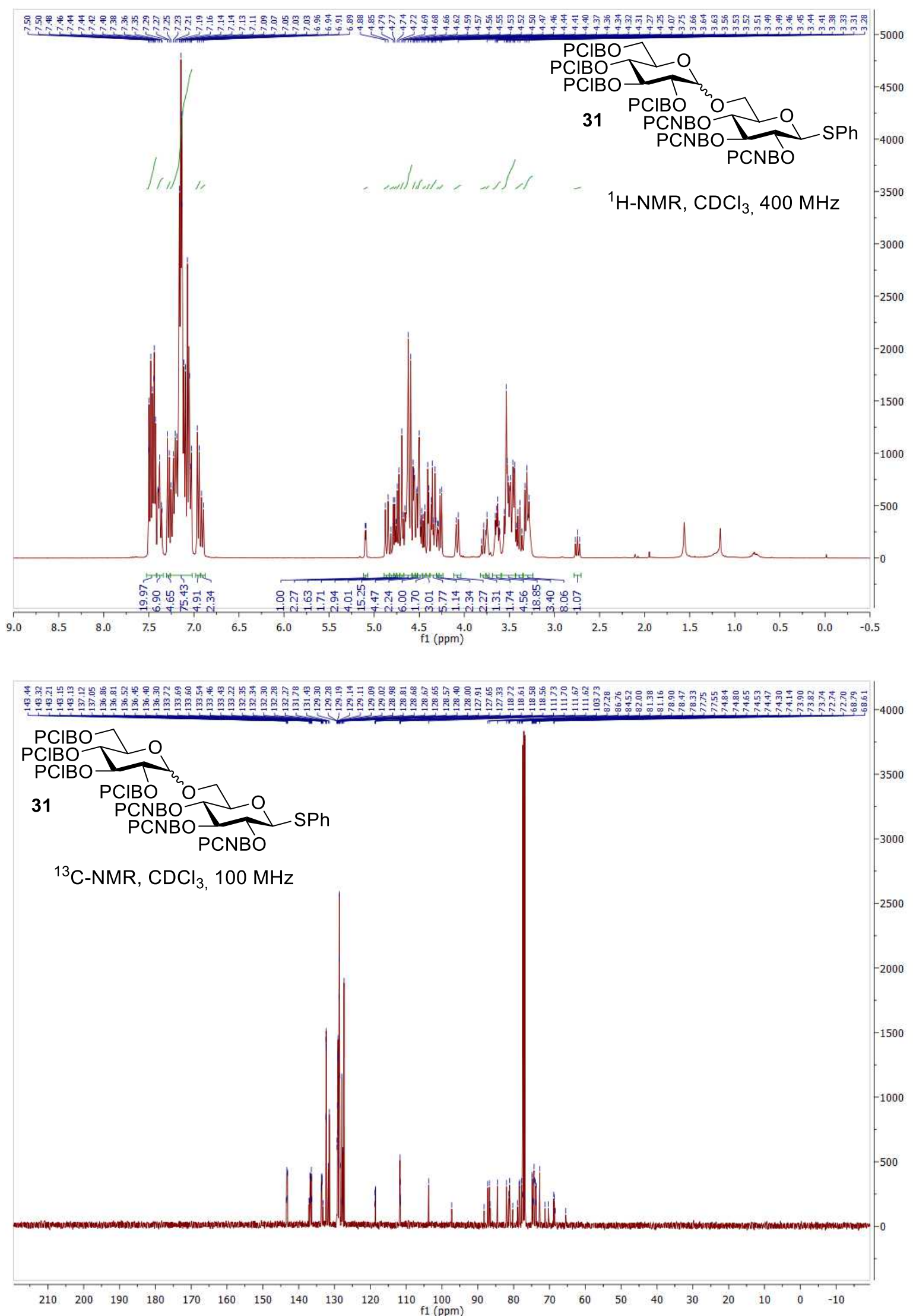

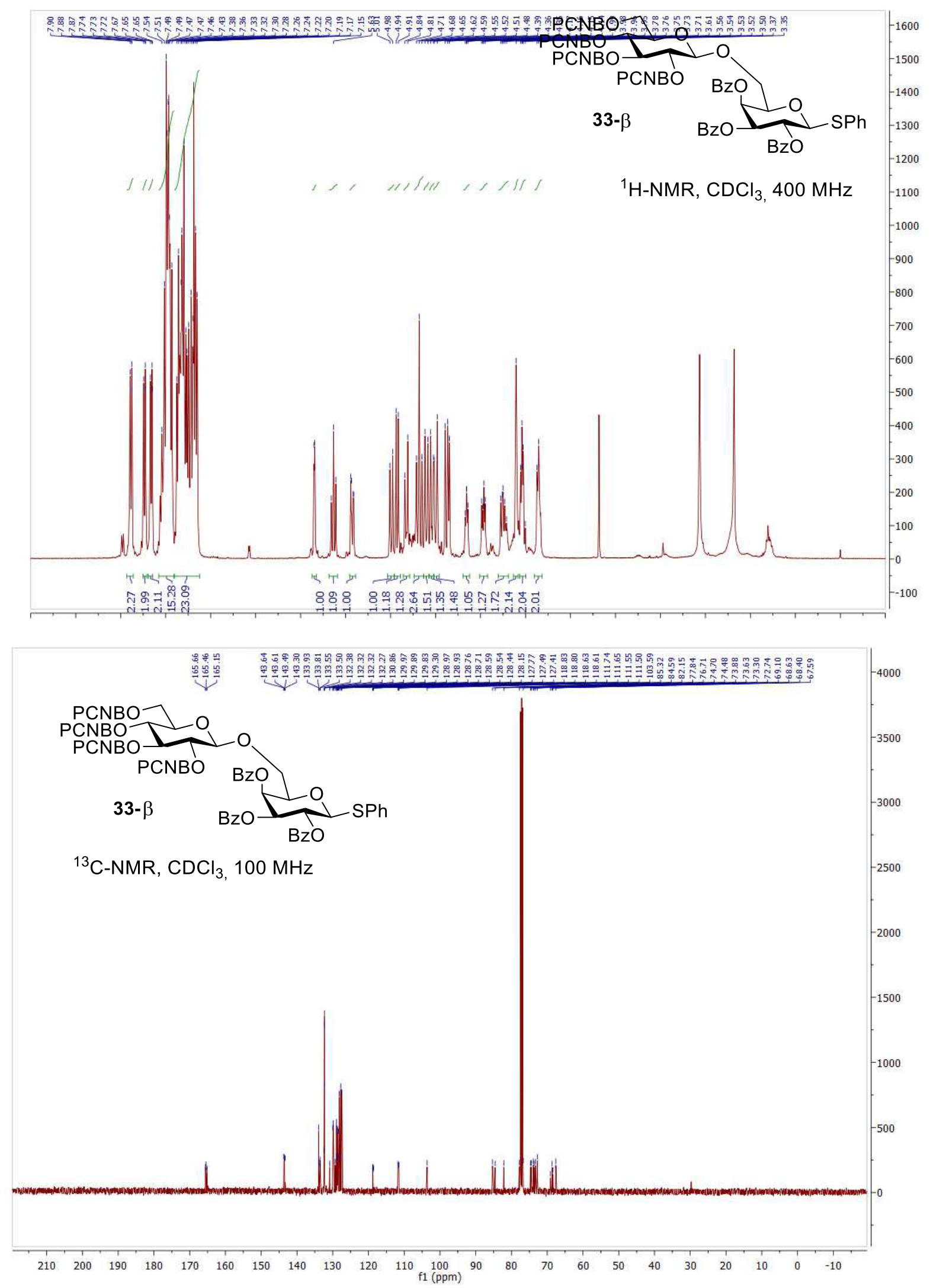

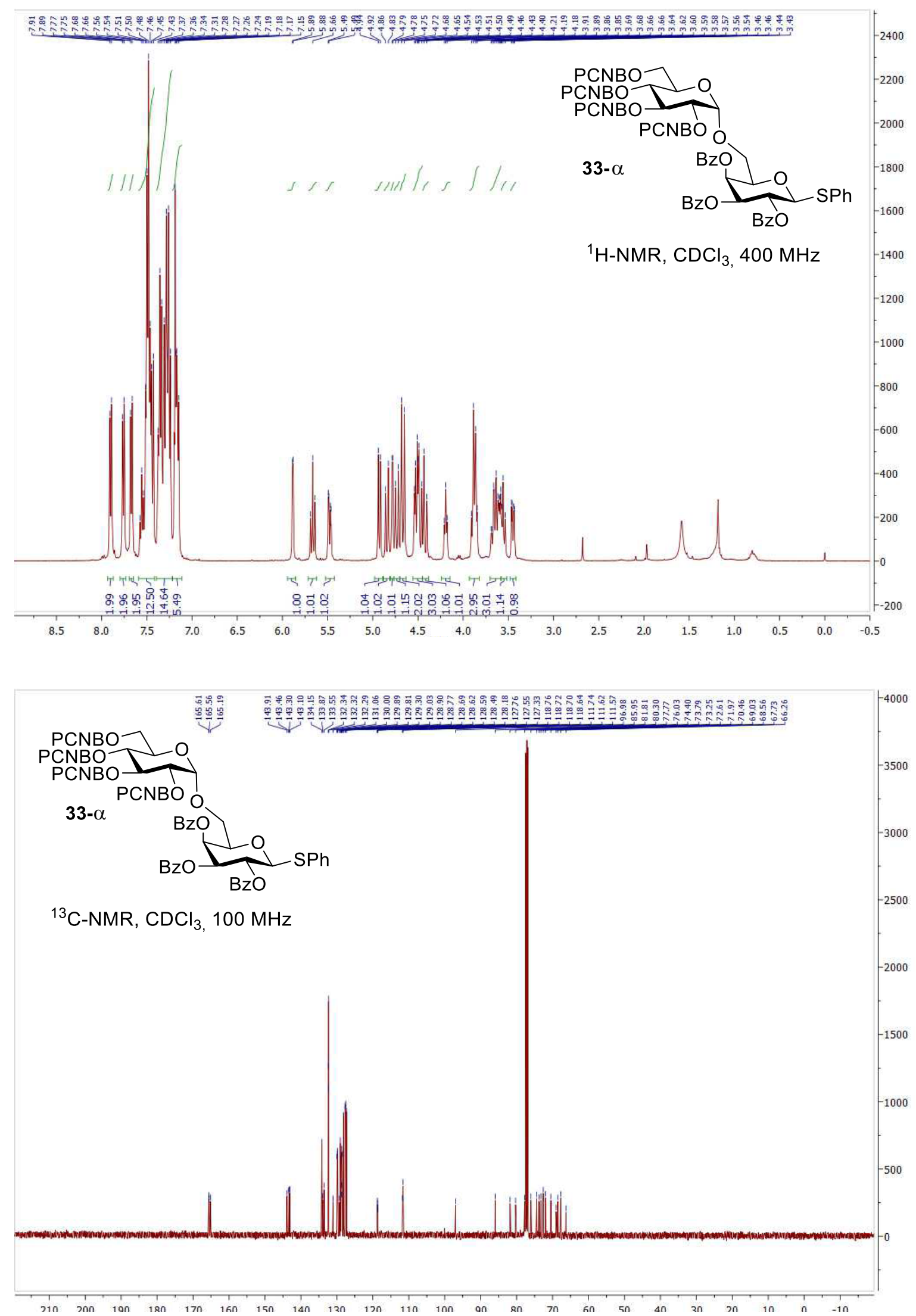

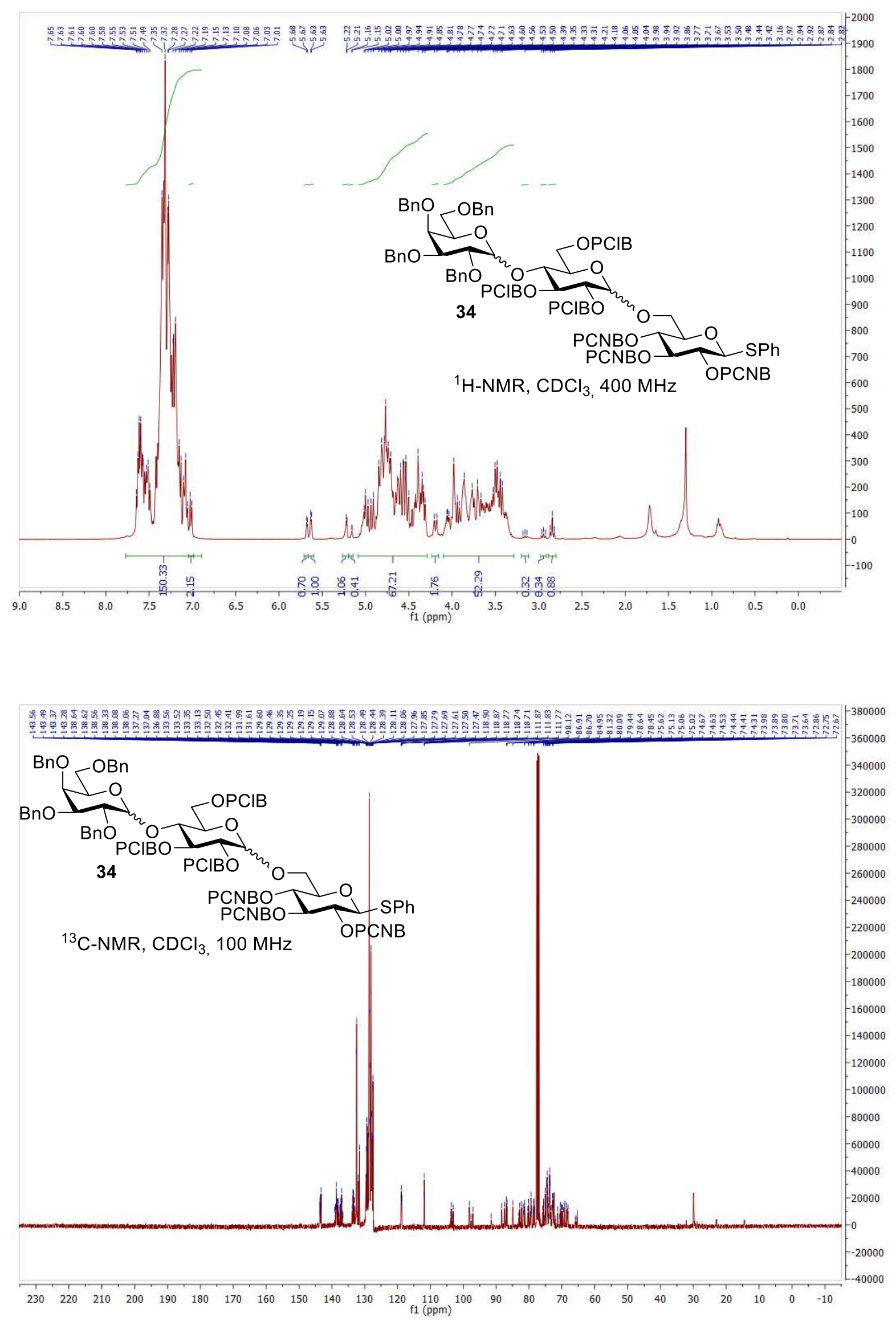

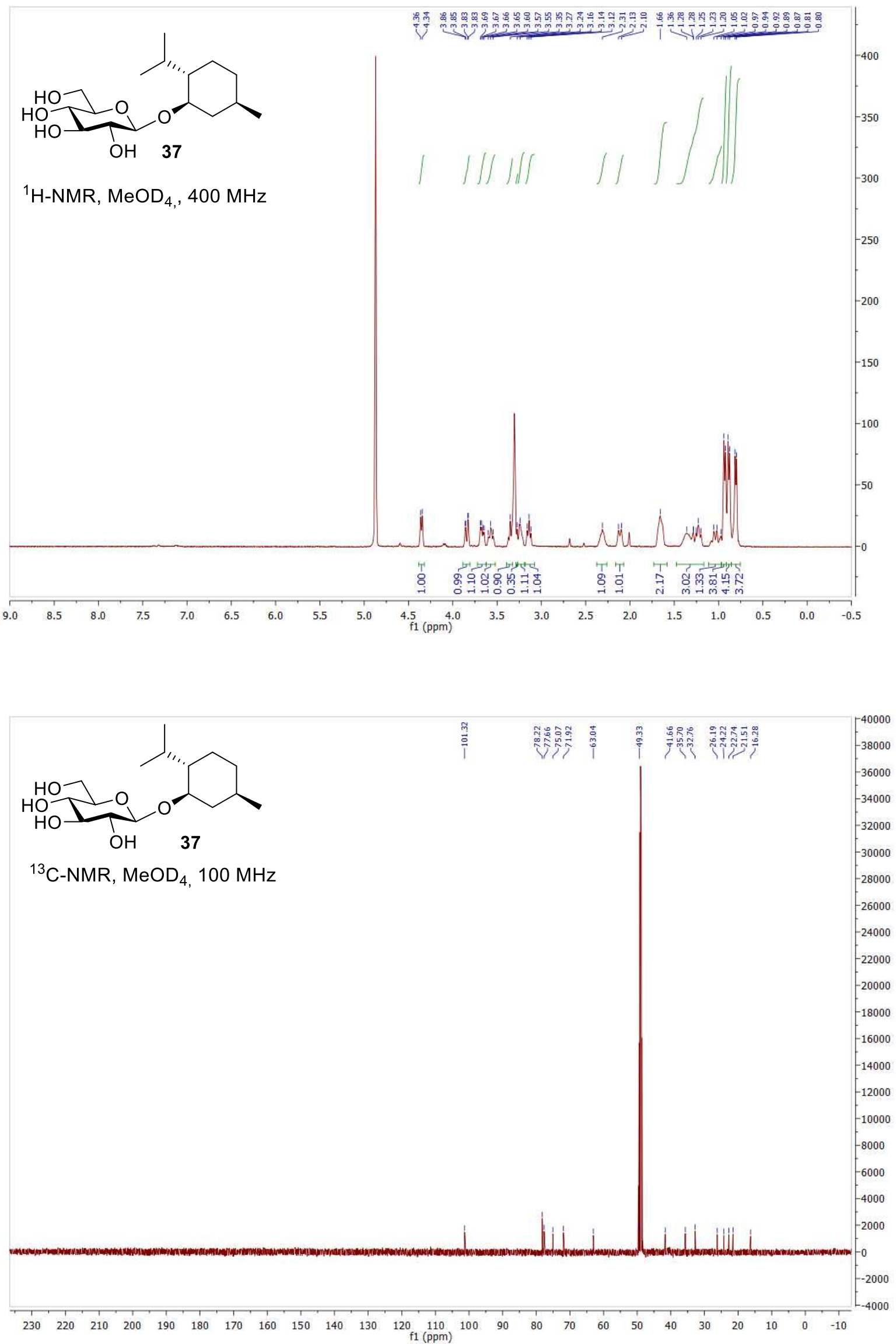